NBER WORKING PAPER SERIES

\title{
CAN A SUMMER MAKE A DIFFERENCE? THE IMPACT OF THE AMERICAN ECONOMIC ASSOCIATION SUMMER PROGRAM ON MINORITY STUDENT OUTCOMES
}

\author{
Charles M. Becker \\ Cecilia Elena Rouse \\ Mingyu Chen \\ Working Paper 20407 \\ http://www.nber.org/papers/w20407 \\ NATIONAL BUREAU OF ECONOMIC RESEARCH \\ 1050 Massachusetts Avenue \\ Cambridge, MA 02138 \\ August 2014
}

This paper grew out of a project with Gregory Price of Morehouse College and Sue Stockly of Eastern New Mexico University. We owe them both a major intellectual debt. We also have benefited from excellent research assistance from Ming Gu and are grateful to Edward Freeland and his colleagues at Princeton's Survey Research Center. Francisca Antman, Peter Arcidiacono, Will Dobbie, Don Fullerton, Gregory Price and Juan Carlos Suarez have provided valuable, detailed comments for which we are truly appreciative. We thank the Princeton University Industrial Relations Section for generously funding the project. All errors in fact or interpretation are ours. The views expressed herein are those of the authors and do not necessarily reflect the views of the National Bureau of Economic Research.

At least one co-author has disclosed a financial relationship of potential relevance for this research. Further information is available online at http://www.nber.org/papers/w20407.ack

NBER working papers are circulated for discussion and comment purposes. They have not been peerreviewed or been subject to the review by the NBER Board of Directors that accompanies official NBER publications.

(C) 2014 by Charles M. Becker, Cecilia Elena Rouse, and Mingyu Chen. All rights reserved. Short sections of text, not to exceed two paragraphs, may be quoted without explicit permission provided that full credit, including $(\mathcal{C}$ notice, is given to the source. 
Can a Summer Make a Difference? The Impact of the American Economic Association Summer Program on Minority Student Outcomes

Charles M. Becker, Cecilia Elena Rouse, and Mingyu Chen

NBER Working Paper No. 20407

August 2014

JEL No. I21,I24,J15

\begin{abstract}
In the 1970s, the American Economic Association (AEA) was one of several professional associations to launch a summer program with the goal of increasing racial and ethnic diversity in its profession. In this paper we estimate the effectiveness of the AEA's program which, to the best of our knowledge, is the first to rigorously study such a summer program. Using a comparison group consisting of those who applied to, but did not attend, the program and controlling for an array of background characteristics, we find that program participants were over 40 percentage points more likely to apply to and attend a $\mathrm{PhD}$ program in economics, 26 percentage points more likely to complete a $\mathrm{PhD}$, and about 15 percentage points more likely to ever work in an economics-related academic job. Using our estimates, we calculate that the program may directly account for 17-21 percent of the PhDs awarded to minorities in economics over the past 20 years.
\end{abstract}

Charles M. Becker

Department of Economics

Duke University

213 Social Sciences Building

Box 90097

Durham, NC 27708-0097

cbecker@duke.edu

Cecilia Elena Rouse

Woodrow Wilson School of Public

and International Affairs

Princeton University

Princeton, NJ 08544-1013

and NBER

rouse@princeton.edu
Mingyu Chen

Department of Economics

Princeton University

NJ 08544

mingyuc@princeton.edu 


\section{Introduction}

Underrepresentation of minorities in higher education has been the focus of sustained attention in the U.S. for decades. Lack of preparation, information, and resources as well as residual discrimination have been identified as potential reasons for this underrepresentation, prompting policymakers and educators to adopt counteracting strategies such as affirmative action in admissions, scholarships, and enrichment programs. Perhaps the most controversial of these programs is affirmative action in admissions. Studies examining the impact of affirmative action bans generally find that these bans decrease the likelihood that minority students apply to and enroll in top-tier institutions (e.g., Long, 2004; Dickson, 2006; Backes, 2012; Hinrichs, 2012). Similarly, interventions in the spirit of affirmative action, such as quotas and preferential treatment in laboratory designs, suggest that this approach is effective at increasing gender and racial diversity (e.g., Balafoutas and Sutter, 2012; Niederle, Segal, and Vesterlund, 2013; Schotter and Weigelt, 1992). ${ }^{1}$ However, given political and legal controversies surrounding affirmative action, many have turned to other strategies for increasing the representativeness of minority students in institutions of higher education.

Providing enrichment for students so that they are better prepared for further academic study is a well-established, though little-researched approach, to increasing academic diversity. For example, for the past fifty years the federal government has funded college preparatory programs, such as Upward Bound and Talent Search. While the research base for these programs is relatively thin, the estimated impacts on student educational outcomes (such as college attendance or the type of institution attended) have

\footnotetext{
${ }^{1}$ In addition, several theoretical studies have examined the implications of affirmative action for college admission, future earnings, and wage inequality (see, e.g., Chan and Eyster, 2003; Moro and Norman, 2003; Arcidiacono, 2005).
} 
been surprisingly mixed (see, e.g., Haskins and Rouse 2013). There is even less evidence on the effectiveness of enrichment programs to prepare students for graduate programs with the aim of addressing underrepresentation in specific professions, although such programs exist in several fields. For example, the American Economic Association (AEA), American Political Science Association (APSA), and the Public Policy and International Affairs Program (PPIA) have sponsored summer enrichment programs for the past 30 or more years. ${ }^{2,3}$

It is straightforward to understand why the AEA elected to focus on increasing diversity in its profession: in the late-1970s only 3 to 5 percent of doctorates in economics received by US citizens and permanent residents were awarded to minorities traditionally underrepresented in the profession (African Americans, Hispanics, and Native Americans), or about 23 new PhDs, each year (Collins 2000). This lack of diversity was worrisome because economic analysis is likely to benefit from differing perspectives and priorities among those in the profession; in addition, a lack of role models in institutions of higher education may have been discouraging younger

\footnotetext{
${ }^{2}$ Other professions offer slightly different kinds of programs with the shared goal of increasing diversity. For instance, the American Sociological Association runs the Minority Fellowship Program that provides mentoring and financial support to minority applicants to graduate programs and current $\mathrm{PhD}$ students. As another example, the Minority Legal Education Resources operates the Bar Process Management Program to assist minorities in passing the Illinois Bar Exam and provide them professional advice.

${ }^{3}$ Around the time that efforts were starting to increase racial and ethnic diversity in many professions, there were also efforts to increase representation of women. For example, the American Economic Association started focusing efforts on increasing the proportion of women in economics in the 1970s. Since then, the percentage of women receiving doctorates in economics has increased from 11 percent in 1975 to 35 percent in 2011, a trend that can be attributed to a variety of factors, including programs designed to address the imbalance (American Economic Association, 1976; McElroy, 2013; Kahn, 1995; Ginther and Kahn, 2004; Hale and Regev, 2013). Notably, Blau, et al. (2010) report findings from the first randomized study of the AEA's mentoring program for junior female economists. They find that the mentoring program had a positive effect on a number of professional outcomes, such as the number of top-tier publications, the total number of publications, and the number of successful federal grants earned by individuals randomly assigned a mentor compared to those randomly assigned to the control group.
} 
generations of minority students from entering the profession (Collins 2000; Chung 2000) and may have adversely affected minority students' performance (Fairlie et al., 2014).

Unfortunately, after some initial improvement, progress has stalled more recently. As shown in Figure 1, the percentage of economics PhDs awarded to minorities has fluctuated around 8 percent since the mid-1990s, which means on average about 30 new $\mathrm{PhDs}$ each year. ${ }^{4}$ As a sobering contrast, the percentage of minorities receiving doctorates has experienced a steady increase in other social sciences and in the science, technology, engineering, and mathematics (STEM) fields.

Given the lack of significant improvement in the racial and ethnic representativeness of doctorates in economics, a key question is whether the AEA's Summer Program has been effective at improving the diversity of the economics profession. To address this question and evaluate the success of the program, we use data from over one-third of AEASP participants between its inception in 1974 and 2010, and a comparison group of students who applied to the program but did not attend. While not a randomized control group, the comparison group enables us to assess the program's impact on a variety of graduate school and professional outcomes. Although we control for a variety of background characteristics, we note that there may be residual unobserved differences between the AEASP participants and those in the comparison group that bias the estimated impacts. That said, to the best of our knowledge, this is the first evaluation that uses a comparison group to assess an (summer) enrichment program that focuses on disadvantaged and minority groups. ${ }^{5}$

\footnotetext{
${ }^{4}$ Similarly, the percentage of bachelor's degrees in economics awarded to minorities has remained around 10-12 percent since 1995 (Rouse 2013).

${ }^{5}$ In a related paper, Price (2005) examines the research productivity of Black American economists, and alternately using propensity score matching (on observables) and Heckman corrections (to control for
} 
Overall, we find that the AEA's Summer Program participants were over 40 percentage points more likely to apply to and attend a $\mathrm{PhD}$ program in economics, 26 percentage points more likely to complete a $\mathrm{PhD}$, and about 15 percentage points more likely to ever work in an economics-related academic job. Using these estimates, we calculate that the program may directly account for $17-21$ percent of the minority $\mathrm{PhDs}$ in economics over the past 20 years. As such, the results from this analysis suggest that relatively intensive, but short, enrichment programs can be an effective tool for improving diversity in at least economics, and likely other professions.

The rest of the paper is organized as follows. In the next section we describe the AEA Summer Program and its student population. In section III we present the data, including our survey and its implementation and the estimation strategy. We present the results in section IV. Section V concludes.

\section{Background on the American Economic Association Summer Program}

\section{The Program}

With the stated objective of increasing the numbers of professional economists from underrepresented minority groups who have been historically disadvantaged in the American context, the AEA Summer Program began regular operation at the University of California, Berkeley in $1974 .^{6}$ Laudably, the program completed its $39^{\text {th }}$ session in

unobserved selection), finds that conditional on being an economist, AEASP participants were somewhat more likely to have published in major journals, received support from the National Science Foundation, and to have NBER membership than those who did not attend.

${ }^{6}$ Initially, "underrepresented in the American context" largely meant African American and Native American. Since about the mid-1970s this has broadened to include Hispanics, Filipino-Americans, Pacific Islanders, and others. Scholarship support was generally, but not always, restricted to these groups, although a small number of non-minority participants also have received financial aid. There have also been a very small number of foreign, non-permanent resident participants; to our knowledge, these students did not receive scholarship support unless they had refugee status. The presence of non-minority students 
2013. ${ }^{7}$ Table 1 shows the universities that have hosted the program since its inception, the years of operation, and the annual average number of participants at each institution. ${ }^{8}$ Since the beginning, the AEASP has included just fewer than 1,000 participants, or about 25 per year; hosts have run the program for an average of 3.7 years.

The program itself has varied over time. One reason for the variation is the resources of the host institution and external funding support. As a result, while the typical program has been 7-8 weeks long, it has ranged from as few as 5 weeks at the University of New Mexico (UNM) to 9 weeks at Duke. Further, while on average about 25 students have participated each year (see Table 1), participant numbers have ranged from fewer than 20 at University of Texas, Austin (Texas) to over 30 at Duke. Another reason for the variation has been the director's interpretation of the objective of the program. Some directors, especially those earlier on, have aimed to increase the likelihood that students already interested in economics and from relatively competitive undergraduate institutions could enroll in and successfully complete a graduate program in an academically rigorous (think "Top 10") department. Others have focused on "high value added" students who were also interested in economics but who may have been from a less competitive undergraduate institution, who may have not thought seriously of pursuing a career in economics that requires training beyond the bachelor's level, or who may have had lower grades. Leeds (1992) articulated this issue slightly differently in noting that students whose parents were professionals earned substantially higher grades

was driven by legal rulings and university policy, but at no institution were the numbers of non-minority students large.

${ }^{7}$ See Alexis (1975) for a description of the history and first year of the AEASP, and see Collins (2000) for an earlier discussion of the AEA's efforts to increase the representation of minorities in the economics profession.

${ }^{8}$ The program has operated nearly continuously since its inception. The only year the program did not operate was in 2011 as it transitioned from the University of California at Santa Barbara to the University of New Mexico. 
in their undergraduate programs. As a result, directors faced a trade-off between those applicants with the greatest need (and who presumably were least likely to progress on their own) and those applicants most likely to do well (and more likely to progress to doctoral programs on their own). Although the outcomes of interest (e.g., success in a doctoral program and a career in an economics-related profession) are similar, the focus would have affected several decisions of the program directors, such as recruitment and curriculum. While potentially important for the evaluation, as with other aspects of the program that varied, because of small sample size we do not attempt to estimate differential treatment effects by specific program characteristics.

In terms of curriculum, at the outset the program offered what amounted to study of advanced intermediate undergraduate material and an introduction to mathematical economics using Alpha Chiang's classic text (Alexis, 1975). Over the years, econometrics and research components were added; since time constraints were binding, something - usually macroeconomics - had to give. In more recent years, advanced coursework at various hosts has included real analysis, probability and mathematical statistics, time series econometrics, and research seminars that focused on micro data analysis. ${ }^{9}$ At some hosts, the content has been delivered in formal course structures that met university requirements and received academic credit; elsewhere, this was not the case. At the University of Colorado, Denver (UC-Denver) and Duke, an average of roughly 6 participants per year returned for a second summer. ${ }^{10}$ Elsewhere, students took

\footnotetext{
${ }^{9}$ Grove et al. (2007), Grove and $\mathrm{Wu}$ (2007), and Krueger and $\mathrm{Wu}$ (2000) find that better math and economics preparation are related to success in graduate programs in economics, suggesting that these elements of the Summer Program should result in improved outcomes for participants.

${ }^{10}$ We treat AEASP recipients as having been exposed to a single treatment regardless of whether they attended for one or two summers. Descriptive statistics also do not count students who return for a second summer. The impact of the second summer may well be important (as detailed in Becker and Price, 2008),
} 
a single program regardless of background level. Even excluding from consideration those hosts that provided two levels, it is safe to say that the content has varied substantially from one host to another.

In terms of cost, it was recognized from the outset that most students needed to earn money during the summer to cover living and tuition costs in the coming academic year; moreover, given the caliber of the students attracted, many if not the majority had competing paid internship opportunities. Thus, the Summer Program generally has paid student living and travel costs, books and software costs, and also has provided a modest stipend, which in recent years has been in the $\$ 2000$ to $\$ 2500$ range. $^{11}$

In addition to student costs and stipends, the program also recruited faculty and teaching assistants. In most years, the program has had a faculty member who served as the director, along with a staff assistant. Some of the faculty and teaching assistants came from the host institution; those who did not were provided transportation and housing. Most faculty and all teaching assistants, regardless of institution, were paid for their work effort. These costs were covered by support from the AEA, public and private foundation grants, university (generally in-kind) contributions, and sponsor in-kind

\footnotetext{
but the recency and number of second-year participants make it difficult to assess the impact on $\mathrm{PhD}$ completion and career outcomes with any reliability.

${ }^{11}$ The stated intent of the AEASP has been to increase minority representation in the economics profession and to our knowledge, all students prior to 1996 received scholarship support. However, starting with the Texas program, the Hopwood $v$. Texas court ruling that forbade explicit consideration of race in admission or other academic decisions caused the formal distinguishing of admission and financial aid decisions, and also led to the admission of non-minority students. Since Texas offered credit for the summer program courses, resident economics majors also were allowed to register for the courses and to participate in the AEASP. Local students were awarded a tuition scholarship from Department of Economics funds and included both minority and non-minority scholars. While the Hopwood ruling was later significantly relaxed, the successor institutions no longer excluded non-minority students. Host institutions UCD and Duke also offered course credit, and allowed regular students to take Summer Program courses. These hosts also gave a small number of non-minority students need-based financial aid. Note that in our analysis non-AEA Summer Program students from the host institution who were enrolled in the courses are not regarded as AEASP students.
} 
contributions. ${ }^{12}$ Institutional in-kind support included (at some, but not all, hosts) classroom and other space, telephones, computer labs, and dormitories. Some hosts also have opened the courses to other students and transferred tuition revenue to the program. Examples of sponsor in-kind support include Coors Brewing Company's hosting of the 2002 and 2003 graduation ceremonies, or the Federal Reserve Board of Governor's sponsoring of a Fed-based faculty member for the four years that the program was at Duke.

Program costs have varied through the years, in part because input costs changed over time and location, in part because input quantities varied markedly and in part because hosts or supporters provided varying amounts of unrecorded in-kind support. Faculty salaries also varied, both because cost structures differ across institutions, and because some schools treated instruction as regular teaching credit, while others paid summer school rates or hired visitors. Above all, inputs varied. At UCD and Duke, costs were higher because some participants returned for a second summer. Administrative commitments also increased (generally to 0.5 of an academic year full-time equivalent for the director) and at Duke, UC-Santa Barbara, and New Mexico there was extensive use of recent alumni as teaching assistants and mentors. Overall, based on budget reports submitted to the AEA to which we have access, costs ranged from $\$ 576,634$ (\$22,178/participant) in 2003 to $\$ 776,676$ (\$25,889/participant) in 2006. In contrast, the budget for the first AEASP program was well under $\$ 300,000$ (and under $\$ 12,500 /$ participant; Alexis, 1975). ${ }^{13}$

\footnotetext{
${ }^{12}$ The program has received support from the National Science Foundation and private foundations, such as the Ford, Mellon, and MacArthur Foundations.

${ }^{13}$ All costs are converted to 2013 dollars using CPI-U.
} 


\section{Applicants}

We do not have complete records on applicants, but based on what we have, it appears that the size of the applicant pool has varied from about 50-75 at Texas to 150 at the University of Wisconsin, Madison. Applicant pool size has varied with economic climate, host institution effort and prestige, and the program's geographic accessibility. ${ }^{14}$ Program directors had little reason to generate a large pool of highly-qualified applicants only to reject most of them. As such, the incentive was to ensure there was a large and diverse pool yielding 50-75 "quality" applicants, and not much of an impetus to go beyond that (and, in any event, recruiting budgets were tight). In short, the program's applicant pool was not large but was highly competitive and in a typical year there would have been at least two or more admissible applicants for each offer made. Further, acceptance rates tended to be high. For example, at Duke and UCD, about 90 percent of those admitted accepted the offer and attended. We have no reason to believe that the percentages elsewhere were different. As a result, few alternates were extended offers. Overall, program size was constrained by funding and host administrative capacity rather than by the size of the applicant pool.

\section{$\underline{\text { Participants }}$}

The composition of the minority student body also changed from one program to another. Reflecting the two potential targets of the program discussed earlier, some schools, such as Temple (Leeds, 1992) and UCD, targeted students from less elite schools

\footnotetext{
${ }^{14}$ The pool often declined during periods of high employment and economic growth. Evidence of this during the years at Temple University is described in Leeds (1992). Data on applicant pools other than Temple come from personal communication and information provided by program directors at Texas and Wisconsin.
} 
for practical as well as ideological reasons; Duke and Stanford did so to a lesser extent as a matter of policy.

Consistent gender and race/ethnicity data for all programs do not exist, but the following points can be made from the (unpublished, but available from the authors) data that do exist. In the early years of the AEASP, the student composition was overwhelmingly African-American. In more recent years, the student bodies have been more evenly divided between African-American and Hispanic backgrounds, though there has been substantial oscillation from one year and host to the next. There also have been small contingents of students (just over 15 percent of our alumni survey respondents) who were Native American or from other historically underrepresented Asian-American groups (of Filipino, Pacific Islander, Hmong, or Vietnamese origin). Some students also have self-identified as multiple racial/ethnic backgrounds. Finally, throughout the program's history, women have comprised slightly less than half of the AEASP student body, though in some years women were the majority. There is no apparent time trend in the share of students who are women.

\section{The Survey and Empirical Strategy}

\section{The Survey}

We started by putting together a sample frame of AEASP participants. We did so with a list of participants from 1974-2007 that we believe to be complete. These data included addresses and, for more recent years, virtually complete e-mail addresses. While e-mail and physical addresses change, informal and some formal (e.g., Facebook 
pages) contacts remain strong, and ultimately it was possible to contact a very large majority of participants.

Fortunately, we also had relatively complete records on all applicants from Stanford, UCD, and Duke with which to construct a comparison group. The advantage of this comparison group is that it represents a group of students who were motivated to apply for the AEA Summer Program and therefore are likely relatively comparable to the participants. At the same time, most of them were not accepted to the program and we only have such data from a limited number of program years. ${ }^{15}$

We conducted a web-based survey from October 2010 to March 2011 to 1,464 individuals. We offered $\$ 25$ as an incentive for participation. In total, 473 individuals responded (for a response rate of 32 percent): 329 applied to and attended the program, and 144 applied to but did not attend. ${ }^{16}$ Of all applicants, 19 percent reported that they were not admitted and 6 percent reported having declined the offer or not attended for reasons such as poor health. Figure 2 shows the number of respondents by treatment and comparison status by the year in which they applied to the program. We had the highest number of responses from the summer sessions of 1989-96 and 2000-07 though there were a remarkable 14 respondents from the 1981 class.

The survey asked for background information, such as parental educational attainment, and about college experiences, any post-graduate studies, and labor market

\footnotetext{
${ }^{15}$ In an attempt to broaden the comparison group, we also asked survey participants to nominate someone with whom the individual went to college but did not apply to the AEA Summer Program, a form of "snowball sampling" (Goodman, 1961). While broadening the sample, this group of students is likely more dissimilar to the participants (on both observable and unobservable characteristics) than those from the unsuccessful applicant comparison group and, importantly, only increased the overall sample by 3 observations. As a result, we focus the analysis on only the applicant comparison group although results are similar when we use all available data and are available on request. Unless otherwise mentioned, no statistics in this paper involve the snowball sample.

${ }^{16}$ There were 8 respondents who did not respond to any outcome-related variables; 5 were AEASP alums and 3 had not attended. We treat them as survey non-respondents.
} 
experiences. Specifically, we asked about six educational outcomes including: whether the respondent had graduated with an economics major, applied to an economics graduate program, applied to an economics doctoral program, attended an economics graduate program, attended an economics doctoral program, and completed a doctoral degree in economics. We also asked about seven employment-related outcomes: whether the respondent currently has an economics-related job, has an economics-related job at an educational or research institution, has an economics-related job in academia, ever has had an economics-related job, ever has had an economics-related job at an educational or research institution, ever has had an economics-related job in academia, and current gross annual salary.

\section{Empirical Strategy}

We think of a potential AEA Summer Program participant as choosing future outcomes as an optimization strategy, subject to constraints on time, financial resources, ability, alternative options, and behavioral parameters, such as his or her discount rate. Empirically, we model the impact of participating in the AEA Summer Program on a variety of "economics-related" outcomes, $Y$, for individual $i$ as follows:

$$
Y_{i}=\alpha+\beta A E A S P_{i}+\boldsymbol{X}_{i} \Theta+v_{i},
$$

where $A E A S P_{i}$ is a treatment status indicator for individual $i$ having participated in the AEA Summer Program, $\boldsymbol{X}_{i}$ is a vector of baseline characteristics, $v_{i}$ is the error term, and $\alpha, \beta$, and $\Theta$ are parameters to be estimated; $\beta$ represents the average effect on outcome $Y$ of having participated in the Summer Program. In the tables that follow, we estimate 
equation (1) using a linear probability model for ease of interpretation; however, we have also implemented probit models which yield similar results (see Appendix Table 1).

We focus our analysis on three subsamples of our dataset. First, we use the full sample, which consists of every individual who applied to the AEASP and all of the available comparison group observations (which we highlight are only from Stanford, UC-Denver, and Duke University). The second "balanced" sample only consists of data from the years the program was at Stanford, UC-Denver, and Duke University; thus, the treatment group also only consists of applicants to those programs. The final sample further limits this "balanced" sample to individuals who applied to those programs through 2002 ("pre-2003") to allow for sufficient time to observe some of the longer-run outcomes.

The key challenge in this analysis is addressing potential unobserved heterogeneity between AEASP participants and non-participants. Table 2 compares background characteristics between participants and non-participants in different subsamples. Columns (1) and (2) present the mean of characteristics of the two available comparison groups: those who applied in all available years to a program at Stanford, UC-Denver, or Duke in column (1) and those who applied to one of these programs before 2003 in column (2). Columns (3), (5), and (7) present the mean characteristics of the treatment groups from our three samples, and columns (4), (6), and (8) show the pvalue of the t-test of the difference in means between treatment and comparison groups.

In each subsample, treatment and comparison groups are fairly similar, although there are some differences. That said, we highlight that nearly all differences are statistically indistinguishable across all of the available observable characteristics using 
the balanced and pre-2003 balanced samples. Specifically, the AEA Summer Program participants were less likely to have graduated from a Historically Black College and University (HBCU) in the full sample and the balanced sample. In addition, nonparticipants are about 5 years younger than participants in the full sample, due to the inclusion of older alumni in the treatment group. They are also 1.5 years older than participants in the pre-2003 balanced sample. Despite these individual differences, an omnibus F-test only suggests that overall the treatment and comparison groups are different when using the full sample where the p-value was 0 . The p-value on the omnibus F-test was 0.57 for the balanced sample and 0.42 for the pre-2003 balanced sample, suggesting that the treatment and comparison groups are statistically similar in these two samples. Nevertheless, we control for observable characteristics in the subsequent analyses.

Due to a low survey response rate (32 percent), we also attempt to explore whether survey respondents were different from non-respondents. Ideally, we would have liked to have regressed a survey response dummy on a series of baseline characteristics, such as those reported in Table 2 using the survey sample. Unfortunately, the only characteristic that we observe for the entire survey sample is whether the individual was female. Across all three subsamples, the coefficient on female is nearly zero and statistically insignificant, which suggests that it is not systematically associated with the survey response decision. ${ }^{17}$ Even more importantly, the impact of whether the individual was female on the decision to respond is not statistically different between the treatment and comparison groups. Appendix Table 2 reports the regression results in

\footnotetext{
${ }^{17}$ As mentioned in footnote 16, we treat the 8 respondents who did not respond to any outcome variables as survey non-respondents. Treating them as respondents does not change any of the results in this exercise.
} 
detail. ${ }^{18}$ While admittedly a limited exercise, the estimates suggest that the estimates of the impact of the AEASP on subsequent outcomes are not affected by differential survey response bias.

\section{Results}

Table 3 presents the main results of the impact of the AEASP on "economicsrelated" outcomes. In columns (1)-(3) we present results using the full sample, columns (4)-(6) show results using the "balanced" sample using data from Stanford, the UCDenver, and Duke, and columns (7)-(9) show results using the subset of data from the balanced sample through 2002 ("pre-2003"). Further, we show estimates of the "raw" impact of the AEA Summer Program on these outcomes as well as estimates conditional on a variety of background characteristics. Specifically, we control for a quadratic in the individual's age, sex, race, ethnicity, number of undergraduate institutions attended, whether she or he received a bachelor's degree from an HBCU, whether she or he received a bachelor's degree from an "elite" institution, and whether at least one parent has a graduate degree. ${ }^{19}$ Estimated coefficients from the full set of covariates are presented in Appendix Table 3.

\section{$\underline{\text { Impacts on Education Outcomes }}$}

\footnotetext{
${ }^{18}$ We also obtained AEA membership status as of June 2014 for the entire survey sample and regressed a survey response dummy on AEA membership. Different from gender, current AEA membership status is not a baseline characteristic. Again, we found no statistically significant difference in the coefficent between treatment and comparison groups. Because AEA membership changes over time and thus may be correlated with other time-varying characteristics such as age, we do not report the results here although they are available upon request.

${ }^{19}$ We control for the age of the respondent as a quadratic in the results shown here. In unreported regressions we have included up to a quartic in age and also limited the sample to those born after 1965. Both strategies generated results similar to those presented here and are available from the authors on request.
} 
The first panel of Table 3 presents the impact of the AEA Summer Program on education outcomes such as the likelihood that an individual majors in economics (defined as economics, agricultural economics, and business/applied economics) or applies to, enrolls in, or completes a graduate program. Starting with the impact on interest in economics at the undergraduate level, we find across the samples that AEASP participants were about 10 percentage points more likely to graduate with a major in economics (broadly defined) although this impact is not statistically significant in the pre2003 balanced sample.

Further, we observe that AEA Summer Program participants were significantly more likely to apply to and attend graduate programs in economics. Specifically, AEA Summer Program participants were nearly 30 percentage points more likely to have applied to and attended a graduate program in economics and over 40 percentage points more likely to have applied to and attended a doctoral program in economics relative to the comparison group. Further, program participants appear to have been about 26 percentage points more likely to complete a $\mathrm{PhD}$ in economics relative to the comparison group in the most restrictive sample - those who applied before 2002 and who have had the greatest amount of time to complete one (see column (9)). Note that while the point estimates vary, the estimated impact of an over 200 percent increase in the likelihood of completing a doctorate in economics (relative to the comparison group mean) holds across the samples, and with and without available covariates.

\section{$\underline{\text { Impacts on Labor Market Outcomes }}$}


The bottom panel of Table 3 presents estimates of the AEA Summer Program on longer-run "economics-related" career outcomes, such as currently having an economicsrelated job or an economics-related academic job, or ever having held a job related to economics. In general, 45 percent of those who applied to the AEA Summer Program were holding an economics-related job at the time of the survey and nearly 60 percent had ever held such a job. These percentages are quite high and reflect the fact that those who applied to the program already had some interest in economics. We focus our discussion on results from the pre-2003 balanced sample below.

We estimate that the AEA Summer Program increased the likelihood that participants were holding, or ever held, a job in an economics-related occupation at the time of the survey by about 11 percentage points, although the estimates are not statistically significant at conventional levels. In contrast, we find that the program significantly improved diversity in the profession as reflected in other measures. For example, we estimate that participants were over 15 percentage points more likely to currently have, or ever had, an academic job related to economics; participants were 30 percentage points more likely ever to have held an economics-related job in an educational or research institution. Given that only about 5 percent of the comparison group had an academic job related to economics at the time of the survey, only 9 percent had ever had such a job, and around one-fifth had ever held a job in an educational or research institution, these impacts are economically quite large.

While impressive, we caution that these estimates must likely be interpreted as upper-bounds of the impact of the program as we do not have a randomly-assigned control group. However, it is notable that the estimates are fairly stable across the three 
samples and with and without controlling for available background characteristics. Further, as shown in Appendix Table 1, they are also robust to using a non-linear probit and to employing propensity score matching. We also note that given the program appears to have encouraged more students to apply to graduate programs, the marginal students may have been weaker which would bias against finding positive impacts on PhD completion and later outcomes. ${ }^{20}$

\section{The AEASP's Cumulative Impact on the Number of Economics Doctorates}

Taking the estimates at face value, we ask what impact the AEASP has likely had on increasing diversity in the economics profession. We limit this thought exercise to the impact on the number of doctorates awarded to minority students as we have outside estimates of the total number of such doctorates from which to form a "universe." Based on the estimates in Table 3, AEASP alumni were 26 percentage points more likely to complete a doctorate in economics than were unsuccessful applicants. To estimate the cumulative impact of the AEASP on the number of doctorates awarded in economics, we use the following simplified calculation. Let $P$ be the number of minority undergraduates who were potential applicants for economics $\mathrm{PhD}$ programs in a typical year, $r$ the likelihood that these students would have eventually completed an economics $\mathrm{PhD}$ without the AEASP intervention, $k$ the AEASP program effect, $A$ the number of students who attended the AEASP in a particular year, and $G$ the total number of minority students from that year who eventually completed an economics PhD. We then have,

\footnotetext{
20 As evidence of the program encouraging more marginal students to apply, the coefficient estimate on AEASP participation in a linear probability model predicting $\mathrm{PhD}$ completion, is negative (although statistically insignificant) conditional on having enrolled in a $\mathrm{PhD}$ program in the pre-2003 balanced sample. These results are available on request.
} 


$$
(P-A) r+A(r+k)=G
$$

This simplifies to

$$
\operatorname{Pr}+A k=G
$$

In any one year the contribution of the AEASP to the proportion of doctorates awarded to minorities is $(A \times k) / G$. The aggregate contribution is therefore the sum of $A \times k$ divided by the sum of $G$ over $T$ years:

$$
\frac{\sum_{t}^{T} A_{t} \mathrm{x} k_{t}}{\sum_{t}^{T} G_{t}}
$$

Assuming the effect of the program on completing an economics $\mathrm{PhD}$ estimated in the pre-2003 balanced sample is similar in other years, we use $k_{t}=0.26$ for all $t^{21}$ Between 1993 and 2012, a total of 628 or 777 economics doctorates were conferred to minorities, depending on the data source. ${ }^{22}$ On average 25 students attended AEASP annually (i.e., 500 students total in 20 years). Therefore, between 1993 and 2012, between 17 and 21 percent $(500 / 628 \times 0.26$ and $500 / 777 \times 0.26)$ of the doctorates in economics conferred to minorities can be directly attributed to the AEASP. ${ }^{23}$ These estimates imply that the program was responsible for an additional $130 \mathrm{PhDs}$ earned in economics and related fields by American minorities over the 20 -year period. Given that AEASP operation costs during this period were roughly $\$ 12$ million $(\$ 600,000 \times 20$, in 2013 dollars $)$, and

\footnotetext{
${ }^{21}$ We assume that the applicants to the AEASP were potential applicants for economics PhD programs in the year following their college graduation and that the treatment effect of the program applies to all minority students who might have applied to a doctoral program in economics.

${ }^{22} \mathrm{We}$ obtain the number of degrees conferred to minorities from two sources, both through NSF's WebCASPAR database. 777 is from the NSF Survey of Earned Doctorates/Doctorate Records File and 628 is from the Integrated Postsecondary Education Data System Completions Survey (IPEDS CS). Note that IPEDS CS data are only available since 1995. We impute 1993 and 1994 values using the average of 1995 1999 data. Both numbers include U.S. citizen and permanent residents only. Minority is defined as Native American, Black and Hispanic, the same way as defined in Figure 1.

${ }^{23}$ In this simple calculation, we assume that minority students awarded an economics PhD between 1993 and 2012 are equal in numbers to future $\mathrm{PhDs}$ generated by potential $\mathrm{PhD}$ applicants during this same 20year period.
} 
ignoring individuals' opportunity costs, the implied financial cost of "producing" a new minority $\mathrm{PhD}$ is about $\$ 92,500$.

To get a sense of the magnitude of this figure, consider the cost of alternative strategies to increase racial and ethnic diversity. One strategy might be to identify talented students at institutions that rarely send students directly to doctoral programs (call them "solid-but-non-elite") and pay the cost differential to send them to institutions that do send students directly to doctoral programs (call them "elite"), and, further, set up the students to succeed. A back-of-the-envelope calculation suggests that this strategy, ignoring administrative and advising costs, would require at least $\$ 500,000$ per $\mathrm{PhD}$ produced - roughly five times that of the AEASP. ${ }^{24}$ Alternatively, one might support a program to help minority students to get a master's degree in preparation for doctoral programs. There are an increasing number of these types of programs, and they vary in cost and duration. To our knowledge, of those with a doctoral placement focus, only Duke and Howard have large minority student populations in their economics graduate programs. A back-of-the-envelope calculation, ignoring administrative costs, suggests that this strategy would cost about $\$ 300,000$ per $\mathrm{PhD}$ produced - that is, three times that of the AEASP. ${ }^{25}$

\footnotetext{
${ }^{24}$ In this thought experiment, we assume that the selected participants would need to complete four years of undergraduate study at the elite institution, since most students entering these institutions, and especially those going on to doctoral programs, typically start with calculus and other AP credits. Based on tuition and costs for the 2013-2014 academic year at Duke and North Carolina A\&T State University, we assume that the cost differential between "elite" and "solid-but-non-elite" institutions is roughly $\$ 17,500 /$ semester, or $\$ 140,000$ for a four year course of study (Duke, 2014; NC A\&T, 2014). Living cost differentials add roughly another $\$ 16,000$. The likelihood of a selected student entering a doctoral degree program in Economics is surely no more than 0.5 , while the likelihood of completion conditional upon entering a doctoral program is about 0.6 (Stock et al., 2006; Stock and Siegfried, 2013). The cost of producing a PhD this way is at least $\$ 520,000=\$ 156,000 /(0.5 * 0.6)$.

${ }^{25}$ The cost of completing a master's degree at Howard is approximately $\$ 94,000(\$ 25,000$ tuition/year + $\$ 22,000$ expenses/year). The cost at Duke is approximately $\$ 128,000$ ( $\$ 44,000$ tuition/year $+\$ 20,000$ expenses/year). The unweighted average is $\$ 111,000$; if we generously assume that half of those selected
} 
We are confident there are other, potentially lower cost, ways to increase the number of minority $\mathrm{PhDs}$ and our estimates should not be interpreted as dispositive. However, these simple thought experiments imply that the AEASP is inexpensive relative to obvious alternatives.

\section{Conclusion}

In this paper we estimate a sizeable impact of the AEA summer program (AEASP) on racial and ethnic diversity in the economics profession. Specifically, we find that the program may have increased the likelihood that students pursued graduate work in economics, were more likely to complete a doctorate and were more likely to pursue careers related to economics. These estimates do not, however, take into consideration the impact of the Summer Program on the caliber of the $\mathrm{PhD}$ programs attended by participants nor any indirect impacts generated by having more role models and peers in the profession.

Obviously these estimates did not derive from a controlled experiment. They are, however, fairly robust across a variety of specifications and with the inclusion of covariates. While it is conceivable that residual unobserved differences between the AEASP participants and the comparison group are biasing the estimated impacts, we are encouraged that the coefficient estimates are relatively insensitive to the inclusion of additional covariates. Furthermore, while ultimately we suspect that any selection bias is likely positive, it is also worth noting that many of those AEASP alumni who were the most talented and with the best social skills may have found non-academic careers more

will enter doctoral programs and three fourth will complete the $\mathrm{PhD}$ conditional upon entering a doctoral program, the cost of producing a $\mathrm{PhD}$ via a master's degree program is nearly $\$ 300,000$ per $\mathrm{PhD}$. 
financially rewarding and exciting. The program also appears to have encouraged more marginal students to apply to graduate school which would work against finding a positive impact on post-doctoral outcomes. Finally, selectivity is unlikely to be time invariant, but rather would likely reflect opportunity costs (and the selection goals of the different hosts). Clearly a more rigorous evaluation could (and should) be contemplated to generate more reliable and nuanced estimates of the program, such as the value of a second year.

This final caveat in mind, it is useful to consider why the program has likely been so successful. Most obviously, it has provided mathematics, statistics, writing, presentation, and economic modelling skills of direct use to graduate study. In addition, the shock of being confronted with an overwhelming work load and learning how to deal with it, and more generally improve time management skills, may also have helped to better prepare the students for graduate work. Students have also received advising on how to prepare for graduate study, on the institutions at which they might thrive, on which courses to take in the upcoming academic year prior to applying, and ongoing mentoring from AEASP faculty and administrators while in graduate school and links to subsequent support systems. Finally, the program may have had psychological effects, by boosting confidence, providing a peer support group and introductions to wider networks, and exposure to role models. Better understanding of the mechanisms by which the program may be improving student interest and success in economics would be useful to designing and improving the program in the future. 
Figure 1: Percentage of PhDs Conferred to Minorities, 1995-2012

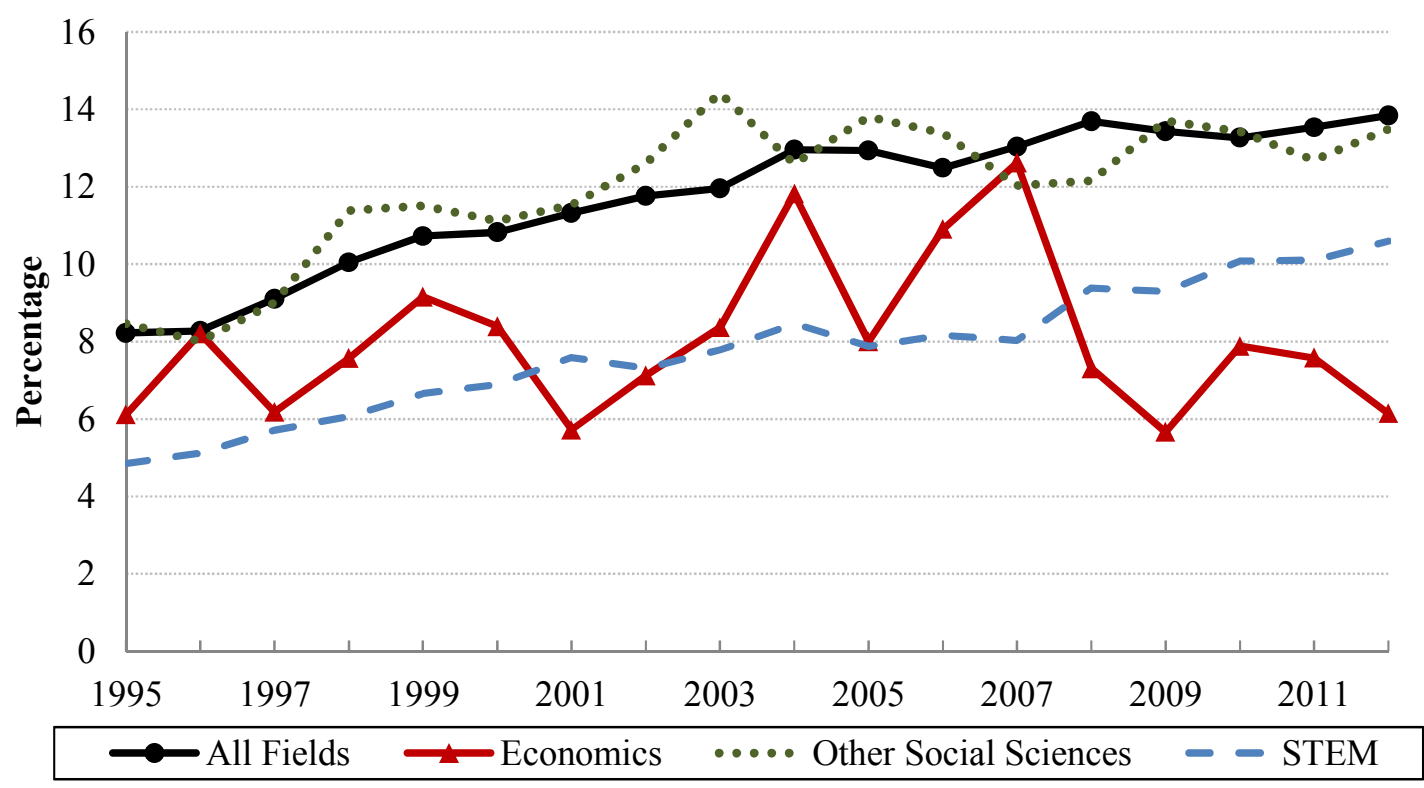

Note: Estimates are computed using data obtained from the Integrated Postsecondary Education Data System Completions Survey through NSF's WebCASPAR database. Degree counts include U.S. citizen and permanent residents only. Minorities include American Indian, Alaska Native, Black, and Hispanic.

Figure 2: Distribution of Survey Respondents in the Application Sample of AEASP Data

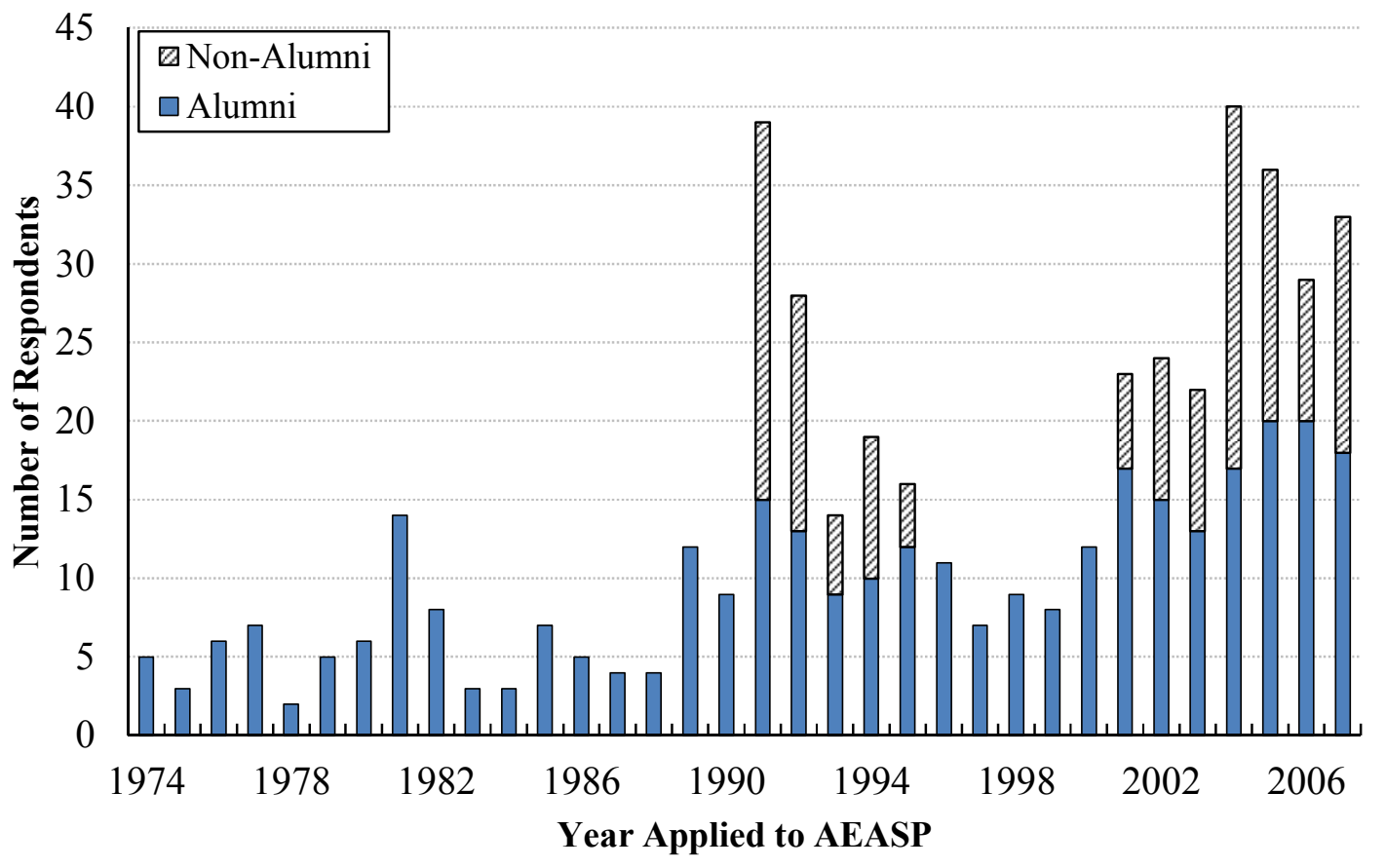


Table 1: AEA Summer Program Enrollment, 1974 - 2012

\begin{tabular}{lccc}
\hline \hline \multicolumn{1}{c}{ AEASP Hosts } & Years & $\begin{array}{c}\text { Total Number } \\
\text { of Students }\end{array}$ & $\begin{array}{c}\text { Average Number of } \\
\text { New Students/Year }\end{array}$ \\
\hline University of California, Berkeley & 1974 & 22 & 22 \\
Northwestern University & $1975-1979$ & 117 & 23 \\
Yale University & $1980-1982$ & 88 & 29 \\
University of Wisconsin, Madison & $1983-1985$ & 87 & 29 \\
Temple University & $1986-1990$ & 137 & 27 \\
Stanford University & $1991-1995$ & 123 & 25 \\
University of Texas, Austin & $1996-2000$ & 96 & 19 \\
University of Colorado, Denver & $2001-2003$ & 79 & 26 \\
Duke University & $2004-2007$ & 120 & 30 \\
University of California, Santa Barbara & $2008-2010$ & 71 & 24 \\
University of New Mexico & 2012 & 20 & 20 \\
Total & & 960 & 25 \\
\hline \hline
\end{tabular}

Note: Student enrollment data refer only to new students and not returning students for Advanced level programs at UC-Denver and Duke. Total students are approximated numbers reported by each program director. AEASP did not operate in 2011. 
Table 2: Survey Respondent Characteristics

\begin{tabular}{|c|c|c|c|c|c|c|c|c|}
\hline & \multicolumn{2}{|c|}{ Comparison Group } & \multicolumn{6}{|c|}{ Treatment Group } \\
\hline & Balanced & $\begin{array}{l}\text { Pre-2003 } \\
\text { Balanced }\end{array}$ & \multicolumn{2}{|c|}{ All Alumni } & \multicolumn{2}{|c|}{ Balanced Alumni } & \multicolumn{2}{|c|}{ Pre-2003 Balanced Alumni } \\
\hline & $\begin{array}{l}\text { Mean } \\
\text { (1) }\end{array}$ & $\begin{array}{l}\text { Mean } \\
\text { (2) }\end{array}$ & $\begin{array}{l}\text { Mean } \\
\text { (3) }\end{array}$ & $\begin{array}{c}\text { Difference } \\
\text { with (1) } \\
\text { (p-value) } \\
\text { (4) }\end{array}$ & $\begin{array}{l}\text { Mean } \\
(5)\end{array}$ & $\begin{array}{c}\text { Difference } \\
\text { with (1) } \\
\text { (p-value) } \\
(6)\end{array}$ & $\begin{array}{l}\text { Mean } \\
(7)\end{array}$ & $\begin{array}{c}\text { Difference } \\
\text { with (2) } \\
\text { (p-value) } \\
(8)\end{array}$ \\
\hline \multicolumn{9}{|l|}{ Personal Chacteristics } \\
\hline Age & 35.88 & 40.31 & 40.45 & 0.00 & 35.01 & 0.25 & 38.94 & 0.09 \\
\hline $\operatorname{Age}^{2}(\div 100)$ & 13.34 & 16.47 & 17.22 & 0.00 & 12.61 & 0.20 & 15.43 & 0.11 \\
\hline Female & 0.44 & 0.46 & 0.44 & 0.98 & 0.44 & 0.95 & 0.44 & 0.84 \\
\hline Hispanic & 0.27 & 0.31 & 0.38 & 0.03 & 0.35 & 0.13 & 0.30 & 0.82 \\
\hline \multicolumn{9}{|l|}{ Race } \\
\hline African American & 0.69 & 0.68 & 0.67 & 0.61 & 0.69 & 0.94 & 0.75 & 0.33 \\
\hline Other races & 0.15 & 0.14 & 0.16 & 0.94 & 0.16 & 0.91 & 0.14 & 0.97 \\
\hline White & 0.15 & 0.18 & 0.17 & 0.56 & 0.15 & 0.98 & 0.11 & 0.23 \\
\hline \multicolumn{9}{|l|}{ Education } \\
\hline Number of undergrad institutions attended & 1.48 & 1.41 & 1.43 & 0.57 & 1.39 & 0.29 & 1.37 & 0.76 \\
\hline \multicolumn{9}{|l|}{ Undergraduate degree institution type } \\
\hline $\mathrm{HBCU}$ & 0.24 & 0.25 & 0.16 & 0.05 & 0.16 & 0.05 & 0.15 & 0.12 \\
\hline Elite research university & 0.27 & 0.30 & 0.32 & 0.26 & 0.30 & 0.48 & 0.31 & 0.87 \\
\hline \multicolumn{9}{|l|}{ Parental Education } \\
\hline At least one parent has graduate degree & 0.40 & 0.38 & 0.43 & 0.64 & 0.44 & 0.51 & 0.46 & 0.29 \\
\hline Both parents below graduate degree & 0.60 & 0.63 & 0.58 & 0.63 & 0.56 & 0.54 & 0.55 & 0.33 \\
\hline Omnibus F-test (p-value) & & & \multirow{2}{*}{\multicolumn{2}{|c|}{0.00}} & \multicolumn{2}{|c|}{0.57} & \multicolumn{2}{|c|}{0.42} \\
\hline Number of observations (range) & $130-143$ & 64-71 & & & \multicolumn{2}{|c|}{$163-179$} & \multicolumn{2}{|c|}{$85-91$} \\
\hline
\end{tabular}

Note: The full sample consists of the all alumni treatment group and comparison group from years of Stanford, UC-Denver, and Duke (S-U-D). The balanced sample consists of the S-U-D treatment and comparison groups. The pre-2003 balanced sample consists of the pre-2003 S-U-D treatment and comparison groups, which is a subset of the balanced sample. Elite research university is defined as a very competitive and very high research activity institution according to the 2010 Carnegie Classification. The p-value of F-statistic is obtained from the regression of the treatment on the listed covariates. 
Table 3: AEA Summer Program Treatment Effect by Outcomes

\begin{tabular}{|c|c|c|c|c|c|c|c|c|c|}
\hline \multirow[b]{2}{*}{ Outcomes } & \multicolumn{3}{|c|}{ Full Sample } & \multicolumn{3}{|c|}{ Balanced Sample } & \multicolumn{3}{|c|}{ Pre-2003 Balanced Sample } \\
\hline & $\begin{array}{c}\text { Mean for } \\
\text { Comparison } \\
\text { (1) }\end{array}$ & $\begin{array}{l}\text { Treatment } \\
\text { Effect } \\
(2)\end{array}$ & $\begin{array}{c}\text { Treatment } \\
\text { Effect with } \\
\text { covariates } \\
\text { (3) }\end{array}$ & $\begin{array}{c}\text { Mean for } \\
\text { Comparison } \\
\text { (4) }\end{array}$ & $\begin{array}{l}\text { Treatment } \\
\text { Effect } \\
(5)\end{array}$ & $\begin{array}{c}\text { Treatment } \\
\text { Effect with } \\
\text { covariates } \\
(6)\end{array}$ & $\begin{array}{c}\text { Mean for } \\
\text { Comparison } \\
\text { (7) }\end{array}$ & $\begin{array}{c}\text { Treatment } \\
\text { Effect } \\
(8)\end{array}$ & $\begin{array}{c}\text { Treatment } \\
\text { Effect with } \\
\text { covariates } \\
\text { (9) }\end{array}$ \\
\hline \multicolumn{10}{|l|}{ Education Outcomes } \\
\hline Graduated with an econ major & 0.62 & $\begin{array}{l}0.12 * * \\
(0.05)\end{array}$ & $\begin{array}{l}0.12 * * \\
(0.05)\end{array}$ & 0.62 & $\begin{array}{l}0.11^{* *} \\
(0.05)\end{array}$ & $\begin{array}{c}0.11^{*} \\
(0.06)\end{array}$ & 0.68 & $\begin{array}{c}0.10 \\
(0.07)\end{array}$ & $\begin{array}{c}0.10 \\
(0.08)\end{array}$ \\
\hline Applied to an econ grad program & 0.43 & $\begin{array}{l}0.27 * * * \\
(0.07)\end{array}$ & $\begin{array}{l}0.30^{* * *} \\
(0.07)\end{array}$ & 0.43 & $\begin{array}{l}0.34 * * * \\
(0.07)\end{array}$ & $\begin{array}{l}0.33 * * * \\
(0.08)\end{array}$ & 0.44 & $\begin{array}{l}0.35^{* * *} \\
(0.10)\end{array}$ & $\begin{array}{l}0.31^{* *} \\
(0.12)\end{array}$ \\
\hline Applied to an econ $\mathrm{PhD}$ program & 0.23 & $\begin{array}{l}0.37 * * * \\
(0.06)\end{array}$ & $\begin{array}{l}0.43 * * * \\
(0.07)\end{array}$ & 0.23 & $\begin{array}{l}0.45^{* * *} \\
(0.07)\end{array}$ & $\begin{array}{l}0.46^{* * * *} \\
(0.07)\end{array}$ & 0.16 & $\begin{array}{l}0.49 * * * \\
(0.09)\end{array}$ & $\begin{array}{l}0.46 * * * \\
(0.11)\end{array}$ \\
\hline Attended an econ grad program & 0.32 & $\begin{array}{l}0.33 * * * \\
(0.06)\end{array}$ & $\begin{array}{l}0.35^{* * *} \\
(0.07)\end{array}$ & 0.32 & $\begin{array}{l}0.39 * * * \\
(0.07)\end{array}$ & $\begin{array}{l}0.38 * * * \\
(0.07)\end{array}$ & 0.34 & $\begin{array}{l}0.41^{* * *} \\
(0.10)\end{array}$ & $\begin{array}{l}0.35^{* * *} \\
(0.11)\end{array}$ \\
\hline Attended an econ $\mathrm{PhD}$ program & 0.14 & $\begin{array}{l}0.37 * * * \\
(0.05)\end{array}$ & $\begin{array}{l}0.40^{* * *} \\
(0.06)\end{array}$ & 0.14 & $\begin{array}{l}0.43 * * * \\
(0.06)\end{array}$ & $\begin{array}{l}0.43 * * * \\
(0.06)\end{array}$ & 0.11 & $\begin{array}{l}0.50^{* * *} \\
(0.08)\end{array}$ & $\begin{array}{l}0.45^{* * *} \\
(0.10)\end{array}$ \\
\hline Completed a $\mathrm{PhD}$ degree in econ & 0.05 & $\begin{array}{l}0.18^{* * *} \\
(0.04)\end{array}$ & $\begin{array}{l}0.17 \text { *** } \\
(0.04)\end{array}$ & 0.05 & $\begin{array}{l}0.14 * * * \\
(0.05)\end{array}$ & $\begin{array}{l}0.16^{* * *} \\
(0.05)\end{array}$ & 0.09 & $\begin{array}{l}0.26^{* * *} \\
(0.08)\end{array}$ & $\begin{array}{l}0.26^{* *} \\
(0.10)\end{array}$ \\
\hline \multicolumn{10}{|l|}{ Labor Market Outcomes } \\
\hline Have an econ-related job & 0.44 & $\begin{array}{l}0.10^{* *} \\
(0.05)\end{array}$ & $\begin{array}{c}0.08 \\
(0.05)\end{array}$ & 0.44 & $\begin{array}{c}0.06 \\
(0.06)\end{array}$ & $\begin{array}{c}0.07 \\
(0.06)\end{array}$ & 0.45 & $\begin{array}{c}0.16^{*} \\
(0.08)\end{array}$ & $\begin{array}{c}0.11 \\
(0.08)\end{array}$ \\
\hline $\begin{array}{l}\text { Have an econ-related job at an } \\
\text { educational or research institution }\end{array}$ & 0.08 & $\begin{array}{l}0.15^{* * *} \\
(0.03)\end{array}$ & $\begin{array}{l}0.14 * * * \\
(0.04)\end{array}$ & 0.08 & $\begin{array}{l}0.16^{* * *} \\
(0.04)\end{array}$ & $\begin{array}{l}0.14 * * * \\
(0.04)\end{array}$ & 0.05 & $\begin{array}{l}0.25 * * * \\
(0.06)\end{array}$ & $\begin{array}{l}0.21 * * * \\
(0.06)\end{array}$ \\
\hline Have an econ-related academic job & 0.05 & $\begin{array}{l}0.12 * * * \\
(0.03)\end{array}$ & $\begin{array}{l}0.10^{* * *} \\
(0.03)\end{array}$ & 0.05 & $\begin{array}{l}0.08^{* *} \\
(0.03)\end{array}$ & $\begin{array}{l}0.08 * * \\
(0.03)\end{array}$ & 0.05 & $\begin{array}{l}0.18 * * * \\
(0.05)\end{array}$ & $\begin{array}{l}0.16^{* * *} \\
(0.06)\end{array}$ \\
\hline Ever had an econ-related job & 0.57 & $\begin{array}{l}0.16^{* * *} \\
(0.05)\end{array}$ & $\begin{array}{l}0.12 * * \\
(0.05)\end{array}$ & 0.57 & $\begin{array}{l}0.15^{* * *} \\
(0.06)\end{array}$ & $\begin{array}{l}0.13 * * \\
(0.06)\end{array}$ & 0.59 & $\begin{array}{l}0.15^{* *} \\
(0.08)\end{array}$ & $\begin{array}{c}0.11 \\
(0.08)\end{array}$ \\
\hline $\begin{array}{l}\text { Ever had an econ-related job at an } \\
\text { educational or research institution }\end{array}$ & 0.21 & $\begin{array}{l}0.24 * * * \\
(0.05)\end{array}$ & $\begin{array}{l}0.22 * * * \\
(0.05)\end{array}$ & 0.21 & $\begin{array}{l}0.28^{* * *} \\
(0.05)\end{array}$ & $\begin{array}{l}0.23 * * * \\
(0.05)\end{array}$ & 0.18 & $\begin{array}{l}0.30^{* * *} \\
(0.07)\end{array}$ & $\begin{array}{l}0.30^{* * *} \\
(0.07)\end{array}$ \\
\hline Ever had an econ-related academic job & 0.07 & $\begin{array}{l}0.15^{* * *} \\
(0.03)\end{array}$ & $\begin{array}{l}0.10^{* * *} \\
(0.03)\end{array}$ & 0.07 & $\begin{array}{l}0.12 * * * \\
(0.04)\end{array}$ & $\begin{array}{l}0.10^{* *} \\
(0.04)\end{array}$ & 0.09 & $\begin{array}{l}0.18^{* * *} \\
(0.06)\end{array}$ & $\begin{array}{l}0.15^{* *} \\
(0.07)\end{array}$ \\
\hline Current gross annual salary (Ln) & 10.93 & $\begin{array}{l}0.41 * * * \\
(0.11)\end{array}$ & $\begin{array}{l}0.19^{*} \\
(0.11)\end{array}$ & 10.93 & $\begin{array}{c}0.18 \\
(0.13)\end{array}$ & $\begin{array}{c}0.11 \\
(0.12)\end{array}$ & 11.25 & $\begin{array}{c}0.13 \\
(0.12)\end{array}$ & $\begin{array}{c}0.11 \\
(0.11)\end{array}$ \\
\hline Number of observations (range) & & $254-468$ & & & $170-318$ & & & $88-160$ & \\
\hline
\end{tabular}


Note: "An academic job" is defined as a job at an educational institution with one of the following faculty ranks: professor, associate/assistant professor, lecturer, and instructor (TA and RA are excluded). Robust standard errors are in parenthesis. Treatment effects with covariates impute missing values in covariates. See Appendix Table 3 for the full specification of covariates and details of the imputation. $*, * *, * *$ represent $\mathrm{p}<0.01, \mathrm{p}<0.05, \mathrm{p}<0.1$, respectively. 


\section{REFERENCES}

Alexis, Marcus. 1975. "Summer Program in Economics for Minority Students." American Economic Review 65 (2): 502-505.

American Economic Association. 1976. "Report of the Committee on the Status of Women in the Economics Profession." American Economic Review 66(2): 509-520.

Arcidiacono, Peter. 2005. "Affirmative Action in Higher Education: How Do Admission and Financial Aid Rules Affect Future Earnings.” Econometrica 73(5): 1477-1524.

Backes, Ben. 2012. "Do Affirmative Action Bans Lower Minority College Enrollment and Attainment? Evidence from Statewide Bans.” Journal of Human Resources 47 (2): 435-455.

Balafoutas, Loukas, and Matthias Sutter. 2012. "Affirmative Action Policies Promote Women and Do Not Harm Efficiency in the Laboratory.” Science 335 (6068): 579-582.

Becker, Charles, Pietro Peretto, Gail McKinnis, and Jerome Dugan, 2007. "2007 Report from the AEASP to the Moody's Foundation," Durham, NC: Duke University Department of Economics, unpublished mimeo.

Becker, Charles M. and Gregory N. Price, 2008. "Curriculum Intensity in Graduate Preparatory Programs: Impact on Performance and Progression to Graduate Study among Minority Students in Economics," in Ronald G. Ehrenberg and Charlotte V. Kuh, Eds. Doctoral Education and the Faculty of the Future. Ithaca, NY: Cornell University Press.

Blau, Francine D., Janet M. Currie, Rachel T.A. Croson, and Donna K. Ginther. 2010. "Can Mentoring Help Female Assistant Professors? Interim Results from a Randomized Trial." American Economic Review 100 (May): 348-352.

Chan , Jimmy, and Erik Eyster. 2003. "Does Banning Affirmative Action Lower College Student Quality.” American Economic Review 93 (3): 858-872.

Chung, Kim-Sau. 2000. "Role Models and Arguments for Affirmative Action." American Economic Review 90(3): 640-648.

Collins, Susan M. 2000. "Minority Groups in the Economics Profession." Journal of Economic Perspectives 14(2): 133-148.

Duke. 2014. "Undergraduate Tuition \& Fees." Accessed on July 28, 2014: http://finance.duke.edu/bursar/TuitionFees/tuition.php

Dickson, Lisa M. 2006. "Does Ending Affirmative Action in College Admissions Lower the Percent of Minority Students Applying to College?" Economics of Education Review 25(1): 109119. 
McElroy, Marjorie B. 2013. "Report: Committee on the Status of Women in the Economics Profession." American Economic Review, 103(3): 744-55.

Fairlie, Robert W., Florian Hoffman, and Philip Oreopoulos. 2014. "A community college instructor like me: race and ethnicity interactions in the classroom." American Economic Review 104(8): 2567-2591.

Ginther, Donna K., and Shulamit Kahn. 2004. "Women in Economics: Moving Up or Falling Off the Academic Career Ladder?” Journal of Economic Perspectives 18(3): 193-214.

Goodman, Leo A. 1961. "Snowball Sampling." Annals of Mathematical Statistics, 32(1): 148-170.

Grove, Wayne, Donald Dutkowsky, and Andrew Grodner. 2007. "Survive Then Thrive: Determinants of Success in the Economics Ph.D. Program," Economic Inquiry 45(4): 864-871.

Grove, Wayne and Stephen Wu. 2007. "The Search for Economics Talent: Doctoral Completion and Research Productivity." American Economic Review 95(2): 506-111.

Hale, Galina, and Tali Regev. 2013. "Gender Ratios at Top PhD Programs in Economics.” Federal Reserve Bank of San Francisco Working Paper 2011-19.

Haskins, Ron and Cecilia Elena Rouse. 2013. "Time for Change: A New Federal Strategy to Prepare Disadvantaged Students for College.” Future of Children Policy Brief (Spring).

Hinrichs, Peter. 2012. "The Effects of Affirmative Action Bans on College Enrollment, Educational Attainment, and the Demographic Composition of Universities." Review of Economics and Statistics 94(3): 712-722.

Kahn, Shulamit. 1995. "Women in the Economics Profession." Journal of Economic Perspectives 9(4): 193-205.

Krueger, Alan and Stephen Wu, 2010, "Forecasting Job Placements of Economics Graduate Students," Journal of Economics Education 31(1): 81-94.

Leeds, Michael A. 1992. "Who Benefits from Affirmative Action? The Case of the AEA Summer Minority Program 1986-90." Journal of Economic Perspectives 6(2): 149-156.

Long, Mark C. 2004. "College Applications and the Effect of Affirmative Action." Journal of Econometrics 121(1-2): 319-342.

Moro, Andrea, and Peter Norman. 2003. "Affirmative Action in a Competitive Economy." Journal of Public Economics 87 (3-4): 567-594.

NC A\&T. 2014. "North Carolina A and T State University Schedule of Costs for Tuition, Fees, Room, and Meals (per Semester) Fall 2013 - Spring 2014.” Accessed on July 28, 2014: 
http://www.ncat.edu/divisions/business-and-finance/comptroller/treasurer/treas-assets/treas-offforms/2013-2014/1314-fee-sheet.pdf

Niederle, Muriel, Carmit Segal, and Lise Vesterlund. 2013. "How Costly is Diversity? Affirmative Action in Light of Gender Differences in Competitiveness." Management Science 59 (1): 1-16.

Price, Gregory N., 2005 (July), "The causal effects of participation in the American Economic Association Summer Minority Program,”Southern Economic Journal 72(1): 78-97.

Rouse, Cecilia Elena. 2013. "Report: Committee on the Status of Minority Groups in the Economics Profession." American Economic Review 103(3): 756-766.

Schotter, Andrew, and Keith Weigelt. 1992. "Asymmetric Tournaments, Equal Opportunity Laws, and Affirmative Action: Some Experimental Results." Quarterly Journal of Economics 107(2), 511539.

Stock, Wendy A., T. Aldrich Finegan, and John J. Siegfried. 2006. "Attrition in Economics Ph.D. Programs," American Economic Review 96(May): 458-466.

Stock, Wendy A., and John J. Siegfried. 2013. "15 Years of Research on Graduate Education in Economics: What Have We Learned?" Bozeman, MT: Department of Economics, Montana State University, unpublished manuscript. 
Appendix Table 1: Treatment Effects from Probit Estimation and Propensity Score Matching (PSM)

\begin{tabular}{|c|c|c|c|c|c|c|c|c|c|}
\hline \multirow[b]{2}{*}{ Outcomes } & \multicolumn{3}{|c|}{ Full Sample } & \multicolumn{3}{|c|}{ Balanced Sample } & \multicolumn{3}{|c|}{ Pre-2003 Balanced Sample } \\
\hline & $\begin{array}{l}\text { OLS } \\
(1)\end{array}$ & $\begin{array}{l}\text { Probit } \\
(2)\end{array}$ & $\begin{array}{l}\text { PSM } \\
(3)\end{array}$ & $\begin{array}{l}\text { OLS } \\
(4)\end{array}$ & $\begin{array}{l}\text { Probit } \\
(5)\end{array}$ & $\begin{array}{c}\text { PSM } \\
(6)\end{array}$ & $\begin{array}{l}\text { OLS } \\
(7)\end{array}$ & $\begin{array}{l}\text { Probit } \\
(8)\end{array}$ & $\begin{array}{c}\text { PSM } \\
(9)\end{array}$ \\
\hline \multicolumn{10}{|l|}{ Education Outcomes } \\
\hline Graduated with an econ major & $\begin{array}{l}0.12^{* *} \\
(0.05)\end{array}$ & $\begin{array}{l}0.12 * * \\
(0.05)\end{array}$ & $\begin{array}{l}0.13^{* *} \\
(0.06)\end{array}$ & $\begin{array}{l}0.11^{*} \\
(0.06)\end{array}$ & $\begin{array}{c}0.11^{*} \\
(0.06)\end{array}$ & $\begin{array}{l}0.12 * * \\
(0.06)\end{array}$ & $\begin{array}{c}0.10 \\
(0.08)\end{array}$ & $\begin{array}{c}0.08 \\
(0.07)\end{array}$ & $\begin{array}{c}0.10 \\
(0.08)\end{array}$ \\
\hline Applied to an econ grad program & $\begin{array}{l}0.30 * * * \\
(0.07)\end{array}$ & $\begin{array}{l}0.32 * * * \\
(0.07)\end{array}$ & $\begin{array}{l}0.32 * * * \\
(0.08)\end{array}$ & $\begin{array}{l}0.33 * * * \\
(0.08)\end{array}$ & $\begin{array}{l}0.33 * * * \\
(0.08)\end{array}$ & $\begin{array}{l}0.35 * * * \\
(0.08)\end{array}$ & $\begin{array}{l}0.31^{* *} \\
(0.12)\end{array}$ & $\begin{array}{l}0.32 * * * \\
(0.11)\end{array}$ & $\begin{array}{l}0.36 * * * \\
(0.13)\end{array}$ \\
\hline Applied to an econ $\mathrm{PhD}$ program & $\begin{array}{l}0.43^{* * *} \\
(0.07)\end{array}$ & $\begin{array}{l}0.50 * * * \\
(0.09)\end{array}$ & $\begin{array}{l}0.45 * * * \\
(0.07)\end{array}$ & $\begin{array}{l}0.46^{* * *} \\
(0.07)\end{array}$ & $\begin{array}{l}0.53^{* * * *} \\
(0.09)\end{array}$ & $\begin{array}{l}0.48^{* * * *} \\
(0.08)\end{array}$ & $\begin{array}{l}0.46^{* * * *} \\
(0.11)\end{array}$ & $\begin{array}{l}0.58^{* * * *} \\
(0.14)\end{array}$ & $\begin{array}{l}0.51 * * * \\
(0.11)\end{array}$ \\
\hline Attended an econ grad program & $\begin{array}{l}0.35^{* * *} \\
(0.07)\end{array}$ & $\begin{array}{l}0.38^{* * * *} \\
(0.08)\end{array}$ & $\begin{array}{l}0.35^{* * *} \\
(0.07)\end{array}$ & $\begin{array}{l}0.38^{* * * *} \\
(0.07)\end{array}$ & $\begin{array}{l}0.41^{* * * *} \\
(0.08)\end{array}$ & $\begin{array}{l}0.40 * * * \\
(0.07)\end{array}$ & $\begin{array}{l}0.35^{* * *} \\
(0.11)\end{array}$ & $\begin{array}{l}0.38^{* * * *} \\
(0.12)\end{array}$ & $\begin{array}{l}0.40^{* * *} \\
(0.13)\end{array}$ \\
\hline Attended an econ $\mathrm{PhD}$ program & $\begin{array}{l}0.40 * * * \\
(0.06)\end{array}$ & $\begin{array}{l}0.49 * * * \\
(0.08)\end{array}$ & $\begin{array}{l}0.40^{* * *} \\
(0.06)\end{array}$ & $\begin{array}{l}0.43^{* * *} \\
(0.06)\end{array}$ & $\begin{array}{l}0.52 * * * \\
(0.08)\end{array}$ & $\begin{array}{l}0.45^{* * * *} \\
(0.06)\end{array}$ & $\begin{array}{l}0.45^{* * *} \\
(0.10)\end{array}$ & $\begin{array}{l}0.58^{* * * *} \\
(0.14)\end{array}$ & $\begin{array}{l}0.50^{* * *} \\
(0.10)\end{array}$ \\
\hline Completed a $\mathrm{PhD}$ degree in econ & $\begin{array}{l}0.17 * * * \\
(0.04)\end{array}$ & $\begin{array}{l}0.21 * * * \\
(0.06)\end{array}$ & $\begin{array}{l}0.19 * * * \\
(0.04)\end{array}$ & $\begin{array}{l}0.16^{* * *} \\
(0.05)\end{array}$ & $\begin{array}{l}0.15^{* * *} \\
(0.04)\end{array}$ & $\begin{array}{l}0.15^{* * *} \\
(0.05)\end{array}$ & $\begin{array}{l}0.26^{* *} \\
(0.10)\end{array}$ & $\begin{array}{l}0.31^{* * *} \\
(0.11)\end{array}$ & $\begin{array}{l}0.25^{* *} \\
(0.10)\end{array}$ \\
\hline \multicolumn{10}{|l|}{ Labor Market Outcomes } \\
\hline Have an econ-related job & $\begin{array}{c}0.08 \\
(0.05)\end{array}$ & $\begin{array}{c}0.09 \\
(0.05)\end{array}$ & $\begin{array}{l}0.12 * \\
(0.06)\end{array}$ & $\begin{array}{c}0.07 \\
(0.06)\end{array}$ & $\begin{array}{c}0.08 \\
(0.06)\end{array}$ & $\begin{array}{c}0.08 \\
(0.06)\end{array}$ & $\begin{array}{c}0.11 \\
(0.08)\end{array}$ & $\begin{array}{c}0.12 \\
(0.09)\end{array}$ & $\begin{array}{l}0.17 * \\
(0.09)\end{array}$ \\
\hline $\begin{array}{l}\text { Have an econ-related job at an } \\
\text { educational or research institution }\end{array}$ & $\begin{array}{l}0.14 * * * \\
(0.04)\end{array}$ & $\begin{array}{l}0.16^{* * *} \\
(0.05)\end{array}$ & $\begin{array}{l}0.14 * * * \\
(0.04)\end{array}$ & $\begin{array}{l}0.14 * * * \\
(0.04)\end{array}$ & $\begin{array}{l}0.14 * * * \\
(0.04)\end{array}$ & $\begin{array}{l}0.14 * * * \\
(0.04)\end{array}$ & $\begin{array}{l}0.21 * * * \\
(0.06)\end{array}$ & $\begin{array}{l}0.24 * * * \\
(0.06)\end{array}$ & $\begin{array}{l}0.26 * * * \\
(0.06)\end{array}$ \\
\hline Have an econ-related academic job & $\begin{array}{l}0.10 * * * \\
(0.03)\end{array}$ & $\begin{array}{l}0.11 * * * \\
(0.04)\end{array}$ & $\begin{array}{l}0.11 * * * \\
(0.03)\end{array}$ & $\begin{array}{l}0.08^{* *} \\
(0.03)\end{array}$ & $\begin{array}{l}0.07 * * * \\
(0.03)\end{array}$ & $\begin{array}{l}0.07 * * \\
(0.03)\end{array}$ & $\begin{array}{l}0.16^{* * * *} \\
(0.06)\end{array}$ & $\begin{array}{l}0.18 * * * \\
(0.06)\end{array}$ & $\begin{array}{l}0.18 * * * \\
(0.06)\end{array}$ \\
\hline Ever had an econ-related job & $\begin{array}{l}0.12 * * \\
(0.05)\end{array}$ & $\begin{array}{l}0.12 * * \\
(0.05)\end{array}$ & $\begin{array}{l}0.14 * * \\
(0.06)\end{array}$ & $\begin{array}{l}0.13 * * \\
(0.06)\end{array}$ & $\begin{array}{l}0.14 * * \\
(0.06)\end{array}$ & $\begin{array}{l}0.14 * * \\
(0.06)\end{array}$ & $\begin{array}{c}0.11 \\
(0.08)\end{array}$ & $\begin{array}{c}0.11 \\
(0.08)\end{array}$ & $\begin{array}{l}0.15^{*} \\
(0.09)\end{array}$ \\
\hline $\begin{array}{l}\text { Ever had an econ-related job at an } \\
\text { educational or research institution }\end{array}$ & $\begin{array}{l}0.22 * * * \\
(0.05)\end{array}$ & $\begin{array}{l}0.25 * * * \\
(0.06)\end{array}$ & $\begin{array}{l}0.23 * * * \\
(0.06)\end{array}$ & $\begin{array}{l}0.23 * * * \\
(0.05)\end{array}$ & $\begin{array}{l}0.25 * * * \\
(0.06)\end{array}$ & $\begin{array}{l}0.25 * * * \\
(0.06)\end{array}$ & $\begin{array}{l}0.30 \text { *** } \\
(0.07)\end{array}$ & $\begin{array}{l}0.34 * * * \\
(0.09)\end{array}$ & $\begin{array}{l}0.36 * * * \\
(0.08)\end{array}$ \\
\hline Ever had an econ-related academic job & $\begin{array}{l}0.10^{* * *} \\
(0.03)\end{array}$ & $\begin{array}{l}0.12 * * * \\
(0.04)\end{array}$ & $\begin{array}{l}0.13 * * * \\
(0.04)\end{array}$ & $\begin{array}{l}0.10^{* *} \\
(0.04)\end{array}$ & $\begin{array}{l}0.09 * * \\
(0.04)\end{array}$ & $\begin{array}{l}0.11^{* * *} \\
(0.04)\end{array}$ & $\begin{array}{l}0.15 * * \\
(0.07)\end{array}$ & $\begin{array}{l}0.16^{* *} \\
(0.07)\end{array}$ & $\begin{array}{l}0.18 * * * \\
(0.06)\end{array}$ \\
\hline Current gross annual salary (Ln) & $\begin{array}{c}0.19^{*} \\
(0.11)\end{array}$ & & $\begin{array}{c}0.15 \\
(0.16)\end{array}$ & $\begin{array}{c}0.11 \\
(0.12)\end{array}$ & & $\begin{array}{c}0.14 \\
(0.13)\end{array}$ & $\begin{array}{c}0.11 \\
(0.11)\end{array}$ & & $\begin{array}{c}0.10 \\
(0.13)\end{array}$ \\
\hline
\end{tabular}


Note: Treatment effects of propensity score matching are estimated using the kernel matching method. The propensity score satisfies the balancing property in all samples. Marginal effects at means are reported for the probit estimation. All treatment effects are estimated using the same specification as in Appendix Table $3 \mathrm{~A}-3 \mathrm{M}$. Robust standard errors are in parentheses. ${ }^{*}, *^{*}, *^{* *}$ represent $\mathrm{p}<0.01, \mathrm{p}<0.05, \mathrm{p}<0.1$, respectively. 
Appendix Table 2: Survey Response Difference by Gender

\begin{tabular}{lccc}
\hline \hline & & & Pre-2003 \\
& $\begin{array}{c}\text { Full Sample } \\
(1)\end{array}$ & $\begin{array}{c}\text { Sample } \\
\text { Balanced } \\
\text { Sample } \\
(2)\end{array}$ & $(3)$ \\
\hline $\begin{array}{l}\text { Panel A } \\
\text { Female }\end{array}$ & 0.00 & 0.01 & 0.03 \\
Observations & $(0.02)$ & $(0.03)$ & $(0.04)$ \\
Panel B & 1464 & 922 & 549 \\
Female & & & \\
& 0.02 & 0.02 & 0.03 \\
Female*AEASP & $(0.04)$ & $(0.04)$ & $(0.04)$ \\
& -0.04 & -0.05 & -0.05 \\
Observations & $(0.05)$ & $(0.07)$ & $(0.09)$ \\
\hline \hline
\end{tabular}

Note: Panel A reports OLS regression results of survey response dummy on female. Panel B adds AEASP and female*AEASP as covariates to the same regression. Coefficients on AEASP are omitted from Panel B. Robust standard errors are in parenthesis. *, **, *** represent $\mathrm{p}<0.01$, $\mathrm{p}<0.05, \mathrm{p}<0.1$, respectively. 
Appendix Table 3A: Impact of AEA Summer Program on Graduating with an Economics Major

\begin{tabular}{|c|c|c|c|c|c|c|}
\hline \multirow[b]{2}{*}{ Variables } & \multicolumn{2}{|c|}{ Full Sample } & \multicolumn{2}{|c|}{ Balanced Sample } & \multicolumn{2}{|c|}{ Pre-2003 Balanced } \\
\hline & $(1)$ & (2) & (3) & $(4)$ & $(5)$ & $(6)$ \\
\hline AEA Summer Program & $\begin{array}{l}0.125^{* *} \\
(0.049)\end{array}$ & $\begin{array}{l}0.119 * * \\
(0.052)\end{array}$ & $\begin{array}{l}0.112^{* *} \\
(0.055)\end{array}$ & $\begin{array}{l}0.107 * \\
(0.057)\end{array}$ & $\begin{array}{c}0.105 \\
(0.072)\end{array}$ & $\begin{array}{c}0.101 \\
(0.077)\end{array}$ \\
\hline Age & & $\begin{array}{c}0.009 \\
(0.022)\end{array}$ & & $\begin{array}{l}-0.012 \\
(0.041)\end{array}$ & & $\begin{array}{c}0.067 \\
(0.086)\end{array}$ \\
\hline $\operatorname{Age}^{2}(\div 100)$ & & $\begin{array}{l}-0.008 \\
(0.026)\end{array}$ & & $\begin{array}{c}0.023 \\
(0.056)\end{array}$ & & $\begin{array}{l}-0.091 \\
(0.111)\end{array}$ \\
\hline Female & & $\begin{array}{c}0.045 \\
(0.045)\end{array}$ & & $\begin{array}{l}0.094^{*} \\
(0.056)\end{array}$ & & $\begin{array}{c}0.010 \\
(0.074)\end{array}$ \\
\hline Hispanic & & $\begin{array}{c}0.017 \\
(0.075)\end{array}$ & & $\begin{array}{l}-0.015 \\
(0.092)\end{array}$ & & $\begin{array}{l}-0.008 \\
(0.156)\end{array}$ \\
\hline Black & & $\begin{array}{c}0.063 \\
(0.090)\end{array}$ & & $\begin{array}{l}-0.000 \\
(0.112)\end{array}$ & & $\begin{array}{c}0.126 \\
(0.186)\end{array}$ \\
\hline Other & & $\begin{array}{c}0.054 \\
(0.086)\end{array}$ & & $\begin{array}{c}0.003 \\
(0.114)\end{array}$ & & $\begin{array}{c}0.034 \\
(0.168)\end{array}$ \\
\hline $\begin{array}{l}\text { \# of undergraduate } \\
\text { institutions attended }\end{array}$ & & $\begin{array}{l}-0.058^{* *} \\
(0.029)\end{array}$ & & $\begin{array}{c}-0.083 * * \\
(0.038)\end{array}$ & & $\begin{array}{l}-0.062 \\
(0.055)\end{array}$ \\
\hline BA from an $\mathrm{HBCU}$ & & $\begin{array}{l}-0.035 \\
(0.062)\end{array}$ & & $\begin{array}{l}-0.081 \\
(0.078)\end{array}$ & & $\begin{array}{c}0.037 \\
(0.092)\end{array}$ \\
\hline BA from an elite institution & & $\begin{array}{l}-0.046 \\
(0.052)\end{array}$ & & $\begin{array}{l}-0.049 \\
(0.066)\end{array}$ & & $\begin{array}{l}-0.046 \\
(0.094)\end{array}$ \\
\hline $\begin{array}{l}\text { At least one parent has } \\
\text { graduate degree }\end{array}$ & & $\begin{array}{l}-0.064 \\
(0.048)\end{array}$ & & $\begin{array}{l}-0.058 \\
(0.060)\end{array}$ & & $\begin{array}{l}-0.075 \\
(0.079)\end{array}$ \\
\hline Number of Observations & 439 & 439 & 298 & 298 & 153 & 153 \\
\hline R-squared & 0.016 & 0.050 & 0.014 & 0.064 & 0.014 & 0.115 \\
\hline
\end{tabular}

Note: Regressions with covariates impute missing values in covariates. For continuous covariates, we impute the missing values by the treatment/comparison group mean and include imputation dummies in regressions. For dummies, we impute the missing values by 0 and include imputation dummies in regressions. The list of covariates listed in this table, plus imputation dummies and a constant term, constitute the full specification for column (2), (4), and (6). It is also the specification used for treatment effect with covariates in Table 3 and Appendix Table 1."Elite" institutions are those identified as those that are "very competitive and very high research activity" by the 2010 Carnegie Classification. Robust standard are errors in parentheses. *, **, *** represent $\mathrm{p}<0.01, \mathrm{p}<0.05, \mathrm{p}<0.1$, respectively. 
Appendix Table 3B: Impact of AEA Summer Program on Applying for an Economics Graduate Program

\begin{tabular}{|c|c|c|c|c|c|c|}
\hline \multirow[b]{2}{*}{ Variables } & \multicolumn{2}{|c|}{ Full Sample } & \multicolumn{2}{|c|}{ Balanced Sample } & \multicolumn{2}{|c|}{ Pre-2003 Balanced } \\
\hline & $(1)$ & $(2)$ & (3) & $(4)$ & $(5)$ & $(6)$ \\
\hline AEA Summer Program & $\begin{array}{c}0.273 * * * \\
(0.071)\end{array}$ & $\begin{array}{c}0.301 * * * \\
(0.073)\end{array}$ & $\begin{array}{c}0.341 * * * \\
(0.074)\end{array}$ & $\begin{array}{c}0.327 * * * \\
(0.078)\end{array}$ & $\begin{array}{c}0.348 * * * \\
(0.105)\end{array}$ & $\begin{array}{l}0.305 * * \\
(0.116)\end{array}$ \\
\hline Age & & $\begin{array}{c}0.034 \\
(0.034)\end{array}$ & & $\begin{array}{c}0.034 \\
(0.051)\end{array}$ & & $\begin{array}{c}0.077 \\
(0.071)\end{array}$ \\
\hline $\operatorname{Age}^{2}(\div 100)$ & & $\begin{array}{l}-0.048 \\
(0.042)\end{array}$ & & $\begin{array}{l}-0.036 \\
(0.068)\end{array}$ & & $\begin{array}{l}-0.079 \\
(0.083)\end{array}$ \\
\hline Female & & $\begin{array}{l}-0.039 \\
(0.061)\end{array}$ & & $\begin{array}{c}0.004 \\
(0.073)\end{array}$ & & $\begin{array}{c}0.024 \\
(0.104)\end{array}$ \\
\hline Hispanic & & $\begin{array}{l}-0.044 \\
(0.098)\end{array}$ & & $\begin{array}{l}-0.020 \\
(0.113)\end{array}$ & & $\begin{array}{l}-0.226 \\
(0.270)\end{array}$ \\
\hline Black & & $\begin{array}{c}0.009 \\
(0.113)\end{array}$ & & $\begin{array}{c}0.064 \\
(0.136)\end{array}$ & & $\begin{array}{l}-0.163 \\
(0.298)\end{array}$ \\
\hline Other & & $\begin{array}{c}0.028 \\
(0.119)\end{array}$ & & $\begin{array}{c}0.141 \\
(0.153)\end{array}$ & & $\begin{array}{c}0.080 \\
(0.243)\end{array}$ \\
\hline $\begin{array}{l}\text { \# of undergraduate } \\
\text { institutions attended }\end{array}$ & & $\begin{array}{c}0.030 \\
(0.036)\end{array}$ & & $\begin{array}{l}-0.009 \\
(0.044)\end{array}$ & & $\begin{array}{l}-0.032 \\
(0.072)\end{array}$ \\
\hline BA from an $\mathrm{HBCU}$ & & $\begin{array}{l}-0.142 * \\
(0.084)\end{array}$ & & $\begin{array}{l}-0.116 \\
(0.097)\end{array}$ & & $\begin{array}{l}-0.040 \\
(0.146)\end{array}$ \\
\hline BA from an elite institution & & $\begin{array}{l}-0.130 * \\
(0.070)\end{array}$ & & $\begin{array}{l}-0.138 \\
(0.087)\end{array}$ & & $\begin{array}{l}-0.234^{*} \\
(0.121)\end{array}$ \\
\hline $\begin{array}{l}\text { At least one parent has } \\
\text { graduate degree }\end{array}$ & & $\begin{array}{c}0.093 \\
(0.062)\end{array}$ & & $\begin{array}{c}0.067 \\
(0.076)\end{array}$ & & $\begin{array}{c}0.053 \\
(0.111)\end{array}$ \\
\hline Number of Observations & 261 & 261 & 176 & 176 & 88 & 88 \\
\hline R-squared & 0.059 & 0.142 & 0.117 & 0.181 & 0.125 & 0.256 \\
\hline
\end{tabular}

Note: Regressions with covariates impute missing values in covariates. For continuous covariates, we impute the missing values by the treatment/comparison group mean and include imputation dummies in regressions. For dummies, we impute the missing values by 0 and include imputation dummies in regressions. The list of covariates listed in this table, plus imputation dummies and a constant term, constitute the full specification for column (2), (4), and (6). It is also the specification used for treatment effect with covariates in Table 3 and Appendix Table 1."Elite" institutions are those identified as those that are "very competitive and very high research activity" by the 2010 Carnegie Classification. Robust standard are errors in parentheses. *, **, *** represent $\mathrm{p}<0.01, \mathrm{p}<0.05, \mathrm{p}<0.1$, respectively. 
Appendix Table 3C: Impact of AEA Summer Program on Applying for an Economics Ph.D. Program

\begin{tabular}{|c|c|c|c|c|c|c|}
\hline \multirow[b]{2}{*}{ Variables } & \multicolumn{2}{|c|}{ Full Sample } & \multicolumn{2}{|c|}{ Balanced Sample } & \multicolumn{2}{|c|}{ Pre-2003 Balanced } \\
\hline & (1) & (2) & (3) & $(4)$ & $(5)$ & (6) \\
\hline AEA Summer Program & $\begin{array}{c}0.373 * * * \\
(0.064)\end{array}$ & $\begin{array}{c}0.430 * * * \\
(0.065)\end{array}$ & $\begin{array}{c}0.450 * * * \\
(0.070)\end{array}$ & $\begin{array}{c}0.458 * * * \\
(0.072)\end{array}$ & $\begin{array}{c}0.487^{* * *} \\
(0.092)\end{array}$ & $\begin{array}{c}0.462 * * * \\
(0.108)\end{array}$ \\
\hline Age & & $\begin{array}{l}0.016 \\
(0.035)\end{array}$ & & $\begin{array}{c}0.038 \\
(0.056)\end{array}$ & & $\begin{array}{l}-0.053 \\
(0.082)\end{array}$ \\
\hline $\operatorname{Age}^{2}(\div 100)$ & & $\begin{array}{l}-0.030 \\
(0.042)\end{array}$ & & $\begin{array}{l}-0.053 \\
(0.074)\end{array}$ & & $\begin{array}{c}0.063 \\
(0.096)\end{array}$ \\
\hline Female & & $\begin{array}{l}-0.030 \\
(0.061)\end{array}$ & & $\begin{array}{l}-0.038 \\
(0.072)\end{array}$ & & $\begin{array}{c}0.010 \\
(0.102)\end{array}$ \\
\hline Hispanic & & $\begin{array}{l}-0.087 \\
(0.092)\end{array}$ & & $\begin{array}{l}-0.106 \\
(0.102)\end{array}$ & & $\begin{array}{l}-0.328 \\
(0.282)\end{array}$ \\
\hline Black & & $\begin{array}{l}-0.077 \\
(0.107)\end{array}$ & & $\begin{array}{l}-0.062 \\
(0.120)\end{array}$ & & $\begin{array}{l}-0.407 \\
(0.305)\end{array}$ \\
\hline Other & & $\begin{array}{l}-0.021 \\
(0.116)\end{array}$ & & $\begin{array}{c}0.070 \\
(0.138)\end{array}$ & & $\begin{array}{l}-0.126 \\
(0.204)\end{array}$ \\
\hline $\begin{array}{l}\text { \# of undergraduate } \\
\text { institutions attended }\end{array}$ & & $\begin{array}{l}0.061^{*} \\
(0.037)\end{array}$ & & $\begin{array}{c}0.039 \\
(0.043)\end{array}$ & & $\begin{array}{c}0.016 \\
(0.086)\end{array}$ \\
\hline $\mathrm{BA}$ from an $\mathrm{HBCU}$ & & $\begin{array}{l}-0.106 \\
(0.091)\end{array}$ & & $\begin{array}{l}-0.061 \\
(0.113)\end{array}$ & & $\begin{array}{l}-0.062 \\
(0.178)\end{array}$ \\
\hline BA from an elite institution & & $\begin{array}{l}-0.125^{*} \\
(0.068)\end{array}$ & & $\begin{array}{l}-0.123 \\
(0.079)\end{array}$ & & $\begin{array}{c}-0.217^{* *} \\
(0.109)\end{array}$ \\
\hline $\begin{array}{l}\text { At least one parent has } \\
\text { graduate degree }\end{array}$ & & $\begin{array}{l}0.152 * * \\
(0.063)\end{array}$ & & $\begin{array}{l}0.197 * * \\
(0.077)\end{array}$ & & $\begin{array}{l}0.193^{*} \\
(0.114)\end{array}$ \\
\hline Number of Observations & 254 & 254 & 170 & 170 & 88 & 88 \\
\hline R-squared & 0.103 & 0.192 & 0.188 & 0.261 & 0.220 & 0.344 \\
\hline
\end{tabular}

Note: Regressions with covariates impute missing values in covariates. For continuous covariates, we impute the missing values by the treatment/comparison group mean and include imputation dummies in regressions. For dummies, we impute the missing values by 0 and include imputation dummies in regressions. The list of covariates listed in this table, plus imputation dummies and a constant term, constitute the full specification for column (2), (4), and (6). It is also the specification used for treatment effect with covariates in Table 3 and Appendix Table 1."Elite" institutions are those identified as those that are "very competitive and very high research activity" by the 2010 Carnegie Classification. Robust standard are errors in parentheses. *, **, *** represent $\mathrm{p}<0.01, \mathrm{p}<0.05, \mathrm{p}<0.1$, respectively. 
Appendix Table 3D: Impact of AEA Summer Program on Attending an Economics Graduate Program

\begin{tabular}{|c|c|c|c|c|c|c|}
\hline \multirow[b]{2}{*}{ Variables } & \multicolumn{2}{|c|}{ Full Sample } & \multicolumn{2}{|c|}{ Balanced Sample } & \multicolumn{2}{|c|}{ Pre-2003 Balanced } \\
\hline & $(1)$ & $(2)$ & (3) & $(4)$ & $(5)$ & $(6)$ \\
\hline AEA Summer Program & $\begin{array}{c}0.329 * * * \\
(0.064)\end{array}$ & $\begin{array}{l}0.351 * * * \\
(0.066)\end{array}$ & $\begin{array}{c}0.387 * * * \\
(0.069)\end{array}$ & $\begin{array}{l}0.381 * * * \\
(0.071)\end{array}$ & $\begin{array}{c}0.412 * * * \\
(0.100)\end{array}$ & $\begin{array}{c}0.347 * * * \\
(0.113)\end{array}$ \\
\hline Age & & $\begin{array}{l}0.056^{*} \\
(0.031)\end{array}$ & & $\begin{array}{c}0.046 \\
(0.045)\end{array}$ & & $\begin{array}{c}0.091 \\
(0.072)\end{array}$ \\
\hline $\operatorname{Age}^{2}(\div 100)$ & & $\begin{array}{l}-0.072 * \\
(0.038)\end{array}$ & & $\begin{array}{l}-0.049 \\
(0.059)\end{array}$ & & $\begin{array}{l}-0.090 \\
(0.084)\end{array}$ \\
\hline Female & & $\begin{array}{l}-0.063 \\
(0.059)\end{array}$ & & $\begin{array}{l}-0.039 \\
(0.070)\end{array}$ & & $\begin{array}{l}-0.052 \\
(0.104)\end{array}$ \\
\hline Hispanic & & $\begin{array}{l}-0.017 \\
(0.093)\end{array}$ & & $\begin{array}{c}0.009 \\
(0.105)\end{array}$ & & $\begin{array}{l}-0.033 \\
(0.239)\end{array}$ \\
\hline Black & & $\begin{array}{c}0.060 \\
(0.108)\end{array}$ & & $\begin{array}{c}0.071 \\
(0.130)\end{array}$ & & $\begin{array}{l}-0.035 \\
(0.277)\end{array}$ \\
\hline Other & & $\begin{array}{c}0.079 \\
(0.115)\end{array}$ & & $\begin{array}{c}0.129 \\
(0.144)\end{array}$ & & $\begin{array}{l}-0.037 \\
(0.217)\end{array}$ \\
\hline $\begin{array}{l}\text { \# of undergraduate } \\
\text { institutions attended }\end{array}$ & & $\begin{array}{c}0.031 \\
(0.035)\end{array}$ & & $\begin{array}{c}0.001 \\
(0.043)\end{array}$ & & $\begin{array}{l}-0.035 \\
(0.073)\end{array}$ \\
\hline BA from an $\mathrm{HBCU}$ & & $\begin{array}{l}-0.164 * * \\
(0.079)\end{array}$ & & $\begin{array}{l}-0.135 \\
(0.092)\end{array}$ & & $\begin{array}{l}-0.043 \\
(0.153)\end{array}$ \\
\hline BA from an elite institution & & $\begin{array}{l}-0.131^{*} \\
(0.069)\end{array}$ & & $\begin{array}{l}-0.099 \\
(0.085)\end{array}$ & & $\begin{array}{l}-0.158 \\
(0.121)\end{array}$ \\
\hline $\begin{array}{l}\text { At least one parent has } \\
\text { graduate degree }\end{array}$ & & $\begin{array}{l}0.104 * \\
(0.062)\end{array}$ & & $\begin{array}{c}0.086 \\
(0.075)\end{array}$ & & $\begin{array}{c}0.150 \\
(0.116)\end{array}$ \\
\hline Number of Observations & 281 & 281 & 194 & 194 & 92 & 92 \\
\hline R-squared & 0.085 & 0.170 & 0.143 & 0.208 & 0.166 & 0.281 \\
\hline
\end{tabular}

Note: Regressions with covariates impute missing values in covariates. For continuous covariates, we impute the missing values by the treatment/comparison group mean and include imputation dummies in regressions. For dummies, we impute the missing values by 0 and include imputation dummies in regressions. The list of covariates listed in this table, plus imputation dummies and a constant term, constitute the full specification for column (2), (4), and (6). It is also the specification used for treatment effect with covariates in Table 3 and Appendix Table 1."Elite" institutions are those identified as those that are "very competitive and very high research activity" by the 2010 Carnegie Classification. Robust standard are errors in parentheses. *, **, *** represent $\mathrm{p}<0.01, \mathrm{p}<0.05, \mathrm{p}<0.1$, respectively. 
Appendix Table 3E: Impact of AEA Summer Program on Attending an Economics Ph.D. Program

\begin{tabular}{|c|c|c|c|c|c|c|}
\hline \multirow[b]{2}{*}{ Variables } & \multicolumn{2}{|c|}{ Full Sample } & \multicolumn{2}{|c|}{ Balanced Sample } & \multicolumn{2}{|c|}{ Pre-2003 Balanced } \\
\hline & $(1)$ & $(2)$ & (3) & (4) & (5) & (6) \\
\hline AEA Summer Program & $\begin{array}{c}0.368 * * * \\
(0.053)\end{array}$ & $\begin{array}{c}0.403 * * * \\
(0.056)\end{array}$ & $\begin{array}{c}0.433 * * * \\
(0.061)\end{array}$ & $\begin{array}{c}0.433 * * * \\
(0.063)\end{array}$ & $\begin{array}{c}0.500 * * * \\
(0.085)\end{array}$ & $\begin{array}{c}0.454 * * * \\
(0.104)\end{array}$ \\
\hline Age & & $\begin{array}{c}0.044 \\
(0.028)\end{array}$ & & $\begin{array}{c}0.045 \\
(0.042)\end{array}$ & & $\begin{array}{l}-0.037 \\
(0.080)\end{array}$ \\
\hline $\operatorname{Age}^{2}(\div 100)$ & & $\begin{array}{l}-0.060^{*} \\
(0.034)\end{array}$ & & $\begin{array}{l}-0.054 \\
(0.055)\end{array}$ & & $\begin{array}{c}0.050 \\
(0.093)\end{array}$ \\
\hline Female & & $\begin{array}{l}-0.027 \\
(0.058)\end{array}$ & & $\begin{array}{l}-0.043 \\
(0.067)\end{array}$ & & $\begin{array}{l}-0.029 \\
(0.099)\end{array}$ \\
\hline Hispanic & & $\begin{array}{l}-0.083 \\
(0.088)\end{array}$ & & $\begin{array}{l}-0.060 \\
(0.097)\end{array}$ & & $\begin{array}{l}-0.147 \\
(0.228)\end{array}$ \\
\hline Black & & $\begin{array}{l}-0.033 \\
(0.102)\end{array}$ & & $\begin{array}{l}-0.046 \\
(0.115)\end{array}$ & & $\begin{array}{l}-0.253 \\
(0.265)\end{array}$ \\
\hline Other & & $\begin{array}{c}0.018 \\
(0.106)\end{array}$ & & $\begin{array}{c}0.021 \\
(0.126)\end{array}$ & & $\begin{array}{l}-0.181 \\
(0.180)\end{array}$ \\
\hline $\begin{array}{l}\text { \# of undergraduate } \\
\text { institutions attended }\end{array}$ & & $\begin{array}{c}0.050 \\
(0.036)\end{array}$ & & $\begin{array}{c}0.019 \\
(0.043)\end{array}$ & & $\begin{array}{c}0.021 \\
(0.083)\end{array}$ \\
\hline BA from an $\mathrm{HBCU}$ & & $\begin{array}{l}-0.145^{*} \\
(0.080)\end{array}$ & & $\begin{array}{l}-0.097 \\
(0.097)\end{array}$ & & $\begin{array}{l}-0.089 \\
(0.171)\end{array}$ \\
\hline BA from an elite institution & & $\begin{array}{c}-0.146^{* *} \\
(0.064)\end{array}$ & & $\begin{array}{l}-0.134 * \\
(0.075)\end{array}$ & & $\begin{array}{l}-0.182 * \\
(0.106)\end{array}$ \\
\hline $\begin{array}{l}\text { At least one parent has } \\
\text { graduate degree }\end{array}$ & & $\begin{array}{l}0.136^{* *} \\
(0.060)\end{array}$ & & $\begin{array}{l}0.157 * * \\
(0.072)\end{array}$ & & $\begin{array}{l}0.260^{* *} \\
(0.112)\end{array}$ \\
\hline Number of Observations & 281 & 281 & 194 & 194 & 92 & 92 \\
\hline R-squared & 0.108 & 0.186 & 0.183 & 0.239 & 0.241 & 0.355 \\
\hline
\end{tabular}

Note: Regressions with covariates impute missing values in covariates. For continuous covariates, we impute the missing values by the treatment/comparison group mean and include imputation dummies in regressions. For dummies, we impute the missing values by 0 and include imputation dummies in regressions. The list of covariates listed in this table, plus imputation dummies and a constant term, constitute the full specification for column (2), (4), and (6). It is also the specification used for treatment effect with covariates in Table 3 and Appendix Table 1."Elite" institutions are those identified as those that are "very competitive and very high research activity" by the 2010 Carnegie Classification. Robust standard are errors in parentheses. *, **, *** represent $\mathrm{p}<0.01, \mathrm{p}<0.05, \mathrm{p}<0.1$, respectively. 
Appendix Table 3F: Impact of AEA Summer Program on Completing an Economics Ph.D. Program

\begin{tabular}{|c|c|c|c|c|c|c|}
\hline \multirow[b]{2}{*}{ Variables } & \multicolumn{2}{|c|}{ Full Sample } & \multicolumn{2}{|c|}{ Balanced Sample } & \multicolumn{2}{|c|}{ Pre-2003 Balanced } \\
\hline & (1) & (2) & (3) & (4) & (5) & (6) \\
\hline AEA Summer Program & $\begin{array}{c}0.179 * * * \\
(0.040)\end{array}$ & $\begin{array}{c}0.170 * * * \\
(0.041)\end{array}$ & $\begin{array}{c}0.140 * * * \\
(0.045)\end{array}$ & $\begin{array}{c}0.156^{* * *} \\
(0.046)\end{array}$ & $\begin{array}{c}0.260 * * * \\
(0.081)\end{array}$ & $\begin{array}{l}0.255^{* *} \\
(0.096)\end{array}$ \\
\hline Age & & $\begin{array}{c}0.065^{* * *} \\
(0.021)\end{array}$ & & $\begin{array}{c}0.043 \\
(0.032)\end{array}$ & & $\begin{array}{c}0.031 \\
(0.109)\end{array}$ \\
\hline $\operatorname{Age}^{2}(\div 100)$ & & $\begin{array}{c}-0.070^{* * *} \\
(0.026)\end{array}$ & & $\begin{array}{l}-0.038 \\
(0.044)\end{array}$ & & $\begin{array}{l}-0.029 \\
(0.141)\end{array}$ \\
\hline Female & & $\begin{array}{l}-0.070 \\
(0.046)\end{array}$ & & $\begin{array}{l}-0.026 \\
(0.051)\end{array}$ & & $\begin{array}{l}-0.043 \\
(0.097)\end{array}$ \\
\hline Hispanic & & $\begin{array}{l}-0.064 \\
(0.064)\end{array}$ & & $\begin{array}{l}-0.062 \\
(0.071)\end{array}$ & & $\begin{array}{l}-0.182 \\
(0.168)\end{array}$ \\
\hline Black & & $\begin{array}{l}-0.095 \\
(0.083)\end{array}$ & & $\begin{array}{l}-0.071 \\
(0.089)\end{array}$ & & $\begin{array}{l}-0.245 \\
(0.219)\end{array}$ \\
\hline Other & & $\begin{array}{l}-0.006 \\
(0.093)\end{array}$ & & $\begin{array}{c}0.006 \\
(0.089)\end{array}$ & & $\begin{array}{l}-0.089 \\
(0.158)\end{array}$ \\
\hline $\begin{array}{l}\text { \# of undergraduate } \\
\text { institutions attended }\end{array}$ & & $\begin{array}{l}-0.019 \\
(0.033)\end{array}$ & & $\begin{array}{c}-0.074 * * \\
(0.031)\end{array}$ & & $\begin{array}{l}-0.064 \\
(0.087)\end{array}$ \\
\hline $\mathrm{BA}$ from an $\mathrm{HBCU}$ & & $\begin{array}{l}-0.070 \\
(0.057)\end{array}$ & & $\begin{array}{l}-0.045 \\
(0.065)\end{array}$ & & $\begin{array}{l}-0.043 \\
(0.138)\end{array}$ \\
\hline BA from an elite institution & & $\begin{array}{l}0.005 \\
(0.054)\end{array}$ & & $\begin{array}{l}0.010 \\
(0.062)\end{array}$ & & $\begin{array}{l}-0.014 \\
(0.106)\end{array}$ \\
\hline $\begin{array}{l}\text { At least one parent has } \\
\text { graduate degree }\end{array}$ & & $\begin{array}{c}0.154^{* * *} \\
(0.050)\end{array}$ & & $\begin{array}{c}0.172 * * * \\
(0.057)\end{array}$ & & $\begin{array}{c}0.300 * * * \\
(0.109)\end{array}$ \\
\hline Number of Observations & 278 & 278 & 191 & 191 & 90 & 90 \\
\hline R-squared & 0.041 & 0.145 & 0.038 & 0.182 & 0.087 & 0.243 \\
\hline
\end{tabular}

Note: Regressions with covariates impute missing values in covariates. For continuous covariates, we impute the missing values by the treatment/comparison group mean and include imputation dummies in regressions. For dummies, we impute the missing values by 0 and include imputation dummies in regressions. The list of covariates listed in this table, plus imputation dummies and a constant term, constitute the full specification for column (2), (4), and (6). It is also the specification used for treatment effect with covariates in Table 3 and Appendix Table 1."Elite" institutions are those identified as those that are "very competitive and very high research activity" by the 2010 Carnegie Classification. Robust standard are errors in parentheses. *, **, *** represent $\mathrm{p}<0.01, \mathrm{p}<0.05, \mathrm{p}<0.1$, respectively. 
Appendix Table 3G: Impact of AEA Summer Program on Having an Economics-Related Job

\begin{tabular}{|c|c|c|c|c|c|c|}
\hline \multirow[b]{2}{*}{ Variables } & \multicolumn{2}{|c|}{ Full Sample } & \multicolumn{2}{|c|}{ Balanced Sample } & \multicolumn{2}{|c|}{ Pre-2003 Balanced } \\
\hline & (1) & (2) & (3) & (4) & $(5)$ & $(6)$ \\
\hline \multirow[t]{2}{*}{ AEA Summer Program } & $0.101 * *$ & 0.084 & 0.064 & 0.075 & $0.155^{*}$ & 0.105 \\
\hline & $(0.050)$ & $(0.053)$ & $(0.056)$ & $(0.058)$ & $(0.079)$ & $(0.082)$ \\
\hline \multirow[t]{2}{*}{ Age } & & 0.025 & & 0.024 & & $-0.196 * *$ \\
\hline & & $(0.024)$ & & $(0.041)$ & & $(0.079)$ \\
\hline \multirow[t]{2}{*}{$\operatorname{Age}^{2}(\div 100)$} & & -0.024 & & -0.025 & & $0.236^{* *}$ \\
\hline & & $(0.029)$ & & $(0.054)$ & & $(0.098)$ \\
\hline \multirow[t]{2}{*}{ Female } & & $-0.105 * *$ & & -0.072 & & -0.077 \\
\hline & & $(0.048)$ & & $(0.058)$ & & $(0.085)$ \\
\hline \multirow[t]{2}{*}{ Hispanic } & & 0.067 & & $0.150 *$ & & 0.166 \\
\hline & & $(0.072)$ & & $(0.084)$ & & $(0.130)$ \\
\hline \multirow[t]{2}{*}{ Black } & & -0.084 & & 0.010 & & 0.105 \\
\hline & & $(0.088)$ & & $(0.108)$ & & $(0.172)$ \\
\hline \multirow[t]{2}{*}{ Other } & & -0.023 & & 0.029 & & 0.177 \\
\hline & & $(0.086)$ & & $(0.113)$ & & $(0.169)$ \\
\hline \multirow{2}{*}{$\begin{array}{l}\text { \# of undergraduate } \\
\text { institutions attended }\end{array}$} & & 0.005 & & 0.025 & & 0.039 \\
\hline & & $(0.030)$ & & $(0.037)$ & & $(0.051)$ \\
\hline \multirow[t]{2}{*}{ BA from an $\mathrm{HBCU}$} & & 0.008 & & -0.040 & & -0.054 \\
\hline & & $(0.066)$ & & $(0.079)$ & & $(0.108)$ \\
\hline \multirow[t]{2}{*}{ BA from an elite institution } & & -0.011 & & 0.041 & & 0.140 \\
\hline & & $(0.055)$ & & $(0.068)$ & & $(0.095)$ \\
\hline \multirow{2}{*}{$\begin{array}{l}\text { At least one parent has } \\
\text { graduate degree }\end{array}$} & & 0.067 & & 0.063 & & 0.096 \\
\hline & & $(0.050)$ & & $(0.061)$ & & $(0.088)$ \\
\hline Number of Observations & 468 & 468 & 318 & 318 & 160 & 160 \\
\hline R-squared & 0.009 & 0.059 & 0.004 & 0.071 & 0.024 & 0.168 \\
\hline
\end{tabular}

Note: Regressions with covariates impute missing values in covariates. For continuous covariates, we impute the missing values by the treatment/comparison group mean and include imputation dummies in regressions. For dummies, we impute the missing values by 0 and include imputation dummies in regressions. The list of covariates listed in this table, plus imputation dummies and a constant term, constitute the full specification for column (2), (4), and (6). It is also the specification used for treatment effect with covariates in Table 3 and Appendix Table 1."Elite" institutions are those identified as those that are "very competitive and very high research activity" by the 2010 Carnegie Classification. Robust standard are errors in parentheses. *, **, *** represent $\mathrm{p}<0.01, \mathrm{p}<0.05, \mathrm{p}<0.1$, respectively. 
Appendix Table 3H: Impact of AEA Summer Program on Having an Economics-Related Job at an Educational/Research Institution

\begin{tabular}{|c|c|c|c|c|c|c|}
\hline \multirow[b]{2}{*}{ Variables } & \multicolumn{2}{|c|}{ Full Sample } & \multicolumn{2}{|c|}{ Balanced Sample } & \multicolumn{2}{|c|}{ Pre-2003 Balanced } \\
\hline & $(1)$ & (2) & $(3)$ & $(4)$ & $(5)$ & (6) \\
\hline AEA Summer Program & $\begin{array}{c}0.152 * * * \\
(0.034)\end{array}$ & $\begin{array}{l}0.141^{* * *} \\
(0.037)\end{array}$ & $\begin{array}{l}0.156^{* * *} \\
(0.040)\end{array}$ & $\begin{array}{l}0.135^{* * *} \\
(0.042)\end{array}$ & $\begin{array}{c}0.253^{* * *} \\
(0.056)\end{array}$ & $\begin{array}{c}0.214 * * * \\
(0.059)\end{array}$ \\
\hline Age & & $\begin{array}{l}-0.006 \\
(0.018)\end{array}$ & & $\begin{array}{c}0.028 \\
(0.025)\end{array}$ & & $\begin{array}{l}-0.048 \\
(0.057)\end{array}$ \\
\hline $\operatorname{Age}^{2}(\div 100)$ & & $\begin{array}{c}0.009 \\
(0.023)\end{array}$ & & $\begin{array}{l}-0.037 \\
(0.033)\end{array}$ & & $\begin{array}{c}0.049 \\
(0.069)\end{array}$ \\
\hline Female & & $\begin{array}{l}-0.063^{*} \\
(0.037)\end{array}$ & & $\begin{array}{l}-0.041 \\
(0.043)\end{array}$ & & $\begin{array}{l}-0.039 \\
(0.073)\end{array}$ \\
\hline Hispanic & & $\begin{array}{c}0.031 \\
(0.062)\end{array}$ & & $\begin{array}{l}0.080 \\
(0.074)\end{array}$ & & $\begin{array}{c}0.067 \\
(0.146)\end{array}$ \\
\hline Black & & $\begin{array}{l}-0.016 \\
(0.074)\end{array}$ & & $\begin{array}{c}0.060 \\
(0.087)\end{array}$ & & $\begin{array}{c}0.066 \\
(0.166)\end{array}$ \\
\hline Other & & $\begin{array}{l}-0.015 \\
(0.069)\end{array}$ & & $\begin{array}{l}0.051 \\
(0.087)\end{array}$ & & $\begin{array}{c}0.046 \\
(0.140)\end{array}$ \\
\hline $\begin{array}{l}\text { \# of undergraduate } \\
\text { institutions attended }\end{array}$ & & $\begin{array}{c}0.008 \\
(0.025)\end{array}$ & & $\begin{array}{l}-0.011 \\
(0.029)\end{array}$ & & $\begin{array}{l}-0.031 \\
(0.041)\end{array}$ \\
\hline $\mathrm{BA}$ from an $\mathrm{HBCU}$ & & $\begin{array}{l}-0.008 \\
(0.051)\end{array}$ & & $\begin{array}{l}-0.034 \\
(0.057)\end{array}$ & & $\begin{array}{l}-0.068 \\
(0.086)\end{array}$ \\
\hline BA from an elite institution & & $\begin{array}{c}-0.090^{* *} \\
(0.042)\end{array}$ & & $\begin{array}{l}-0.077 \\
(0.052)\end{array}$ & & $\begin{array}{l}-0.024 \\
(0.080)\end{array}$ \\
\hline $\begin{array}{l}\text { At least one parent has } \\
\text { graduate degree }\end{array}$ & & $\begin{array}{c}0.132 * * * \\
(0.041)\end{array}$ & & $\begin{array}{c}0.158^{* * *} \\
(0.049)\end{array}$ & & $\begin{array}{l}0.155^{* *} \\
(0.071)\end{array}$ \\
\hline Number of Observations & 447 & 447 & 308 & 308 & 153 & 153 \\
\hline R-squared & 0.032 & 0.073 & 0.042 & 0.093 & 0.103 & 0.160 \\
\hline
\end{tabular}

Note: Regressions with covariates impute missing values in covariates. For continuous covariates, we impute the missing values by the treatment/comparison group mean and include imputation dummies in regressions. For dummies, we impute the missing values by 0 and include imputation dummies in regressions. The list of covariates listed in this table, plus imputation dummies and a constant term, constitute the full specification for column (2), (4), and (6). It is also the specification used for treatment effect with covariates in Table 3 and Appendix Table 1."Elite" institutions are those identified as those that are "very competitive and very high research activity" by the 2010 Carnegie Classification. Robust standard are errors in parentheses. *, **, *** represent $\mathrm{p}<0.01, \mathrm{p}<0.05, \mathrm{p}<0.1$, respectively. 
Appendix Table 3I: Impact of AEA Summer Program on Having an Econ-Related Academic Job

\begin{tabular}{|c|c|c|c|c|c|c|}
\hline \multirow[b]{2}{*}{ Variables } & \multicolumn{2}{|c|}{ Full Sample } & \multicolumn{2}{|c|}{ Balanced Sample } & \multicolumn{2}{|c|}{ Pre-2003 Balanced } \\
\hline & $(1)$ & $(2)$ & (3) & $(4)$ & $(5)$ & $(6)$ \\
\hline AEA Summer Program & $\begin{array}{l}0.121 * * * \\
(0.029)\end{array}$ & $\begin{array}{c}0.095 * * * \\
(0.030)\end{array}$ & $\begin{array}{l}0.081 * * \\
(0.032)\end{array}$ & $\begin{array}{l}0.082 * * \\
(0.034)\end{array}$ & $\begin{array}{c}0.183 * * * \\
(0.054)\end{array}$ & $\begin{array}{c}0.160 * * * \\
(0.060)\end{array}$ \\
\hline Age & & $\begin{array}{c}0.013 \\
(0.016)\end{array}$ & & $\begin{array}{l}0.034 * \\
(0.019)\end{array}$ & & $\begin{array}{l}-0.008 \\
(0.051)\end{array}$ \\
\hline $\operatorname{Age}^{2}(\div 100)$ & & $\begin{array}{l}-0.006 \\
(0.020)\end{array}$ & & $\begin{array}{l}-0.036 \\
(0.026)\end{array}$ & & $\begin{array}{c}0.012 \\
(0.063)\end{array}$ \\
\hline Female & & $\begin{array}{l}-0.032 \\
(0.032)\end{array}$ & & $\begin{array}{l}-0.007 \\
(0.034)\end{array}$ & & $\begin{array}{l}-0.038 \\
(0.071)\end{array}$ \\
\hline Hispanic & & $\begin{array}{l}-0.060 \\
(0.051)\end{array}$ & & $\begin{array}{l}-0.058 \\
(0.059)\end{array}$ & & $\begin{array}{l}-0.006 \\
(0.155)\end{array}$ \\
\hline Black & & $\begin{array}{l}-0.085 \\
(0.065)\end{array}$ & & $\begin{array}{l}-0.026 \\
(0.073)\end{array}$ & & $\begin{array}{c}0.066 \\
(0.167)\end{array}$ \\
\hline Other & & $\begin{array}{l}-0.017 \\
(0.067)\end{array}$ & & $\begin{array}{c}0.023 \\
(0.072)\end{array}$ & & $\begin{array}{c}0.125 \\
(0.142)\end{array}$ \\
\hline $\begin{array}{l}\text { \# of undergraduate } \\
\text { institutions attended }\end{array}$ & & $\begin{array}{c}0.005 \\
(0.023)\end{array}$ & & $\begin{array}{l}-0.025 \\
(0.021)\end{array}$ & & $\begin{array}{l}-0.028 \\
(0.040)\end{array}$ \\
\hline BA from an $\mathrm{HBCU}$ & & $\begin{array}{l}-0.023 \\
(0.044)\end{array}$ & & $\begin{array}{l}-0.044 \\
(0.042)\end{array}$ & & $\begin{array}{l}-0.074 \\
(0.075)\end{array}$ \\
\hline BA from an elite institution & & $\begin{array}{l}-0.043 \\
(0.037)\end{array}$ & & $\begin{array}{l}-0.018 \\
(0.041)\end{array}$ & & $\begin{array}{c}0.010 \\
(0.074)\end{array}$ \\
\hline $\begin{array}{l}\text { At least one parent has } \\
\text { graduate degree }\end{array}$ & & $\begin{array}{l}0.079 * * \\
(0.037)\end{array}$ & & $\begin{array}{l}0.082 * * \\
(0.038)\end{array}$ & & $\begin{array}{c}0.099 \\
(0.068)\end{array}$ \\
\hline Number of Observations & 421 & 421 & 294 & 294 & 144 & 144 \\
\hline R-squared & 0.028 & 0.095 & 0.019 & 0.093 & 0.064 & 0.124 \\
\hline
\end{tabular}

Note: Regressions with covariates impute missing values in covariates. For continuous covariates, we impute the missing values by the treatment/comparison group mean and include imputation dummies in regressions. For dummies, we impute the missing values by 0 and include imputation dummies in regressions. The list of covariates listed in this table, plus imputation dummies and a constant term, constitute the full specification for column (2), (4), and (6). It is also the specification used for treatment effect with covariates in Table 3 and Appendix Table 1."Elite" institutions are those identified as those that are "very competitive and very high research activity" by the 2010 Carnegie Classification. Robust standard are errors in parentheses. *, **, *** represent $\mathrm{p}<0.01, \mathrm{p}<0.05, \mathrm{p}<0.1$, respectively. 


\begin{tabular}{|c|c|c|c|c|c|c|}
\hline \multirow[b]{2}{*}{ Variables } & \multicolumn{2}{|c|}{ Full Sample } & \multicolumn{2}{|c|}{ Balanced Sample } & \multicolumn{2}{|c|}{ Pre-2003 Balanced } \\
\hline & $(1)$ & $(2)$ & (3) & (4) & $(5)$ & $(6)$ \\
\hline AEA Summer Program & $\begin{array}{c}0.156^{* * *} \\
(0.050)\end{array}$ & $\begin{array}{l}0.125 * * \\
(0.052)\end{array}$ & $\begin{array}{c}0.152 * * * \\
(0.056)\end{array}$ & $\begin{array}{l}0.131 * * \\
(0.057)\end{array}$ & $\begin{array}{l}0.150 * * \\
(0.075)\end{array}$ & $\begin{array}{c}0.108 \\
(0.076)\end{array}$ \\
\hline Age & & $\begin{array}{c}0.014 \\
(0.023)\end{array}$ & & $\begin{array}{c}0.037 \\
(0.040)\end{array}$ & & $\begin{array}{c}-0.193 * * * \\
(0.059)\end{array}$ \\
\hline $\operatorname{Age}^{2}(\div 100)$ & & $\begin{array}{l}-0.013 \\
(0.028)\end{array}$ & & $\begin{array}{l}-0.043 \\
(0.053)\end{array}$ & & $\begin{array}{c}0.237 * * * \\
(0.070)\end{array}$ \\
\hline Female & & $\begin{array}{l}-0.072 \\
(0.046)\end{array}$ & & $\begin{array}{l}-0.018 \\
(0.058)\end{array}$ & & $\begin{array}{l}-0.028 \\
(0.081)\end{array}$ \\
\hline Hispanic & & $\begin{array}{l}0.166^{* *} \\
(0.065)\end{array}$ & & $\begin{array}{c}0.249 * * * \\
(0.075)\end{array}$ & & $\begin{array}{l}0.195 * \\
(0.108)\end{array}$ \\
\hline Black & & $\begin{array}{c}0.022 \\
(0.077)\end{array}$ & & $\begin{array}{c}0.031 \\
(0.093)\end{array}$ & & $\begin{array}{l}-0.003 \\
(0.136)\end{array}$ \\
\hline Other & & $\begin{array}{l}-0.011 \\
(0.078)\end{array}$ & & $\begin{array}{l}-0.008 \\
(0.104)\end{array}$ & & $\begin{array}{l}-0.005 \\
(0.145)\end{array}$ \\
\hline $\begin{array}{l}\text { \# of undergraduate } \\
\text { institutions attended }\end{array}$ & & $\begin{array}{l}-0.009 \\
(0.028)\end{array}$ & & $\begin{array}{c}0.000 \\
(0.033)\end{array}$ & & $\begin{array}{l}-0.004 \\
(0.048)\end{array}$ \\
\hline BA from an $\mathrm{HBCU}$ & & $\begin{array}{l}-0.055 \\
(0.067)\end{array}$ & & $\begin{array}{l}-0.071 \\
(0.083)\end{array}$ & & $\begin{array}{c}0.013 \\
(0.105)\end{array}$ \\
\hline BA from an elite institution & & $\begin{array}{l}-0.026 \\
(0.051)\end{array}$ & & $\begin{array}{l}-0.002 \\
(0.064)\end{array}$ & & $\begin{array}{c}0.098 \\
(0.087)\end{array}$ \\
\hline $\begin{array}{l}\text { At least one parent has } \\
\text { graduate degree }\end{array}$ & & $\begin{array}{l}0.108 * * \\
(0.046)\end{array}$ & & $\begin{array}{l}0.099 * \\
(0.058)\end{array}$ & & $\begin{array}{c}0.077 \\
(0.083)\end{array}$ \\
\hline Number of Observations & 443 & 443 & 295 & 295 & 159 & 159 \\
\hline R-squared & 0.024 & 0.079 & 0.025 & 0.108 & 0.025 & 0.166 \\
\hline
\end{tabular}

Note: Regressions with covariates impute missing values in covariates. For continuous covariates, we impute the missing values by the treatment/comparison group mean and include imputation dummies in regressions. For dummies, we impute the missing values by 0 and include imputation dummies in regressions. The list of covariates listed in this table, plus imputation dummies and a constant term, constitute the full specification for column (2), (4), and (6). It is also the specification used for treatment effect with covariates in Table 3 and Appendix Table 1."Elite" institutions are those identified as those that are "very competitive and very high research activity" by the 2010 Carnegie Classification. Robust standard are errors in parentheses. *, **, *** represent $\mathrm{p}<0.01, \mathrm{p}<0.05, \mathrm{p}<0.1$, respectively. 
Appendix Table 3K: Impact of AEA Summer Program on Ever Had an EconomicsRelated Job at an Educational/Research Institution

\begin{tabular}{|c|c|c|c|c|c|c|}
\hline \multirow[b]{2}{*}{ Variables } & \multicolumn{2}{|c|}{ Full Sample } & \multicolumn{2}{|c|}{ Balanced Sample } & \multicolumn{2}{|c|}{ Pre-2003 Balanced } \\
\hline & $(1)$ & (2) & (3) & (4) & $(5)$ & $(6)$ \\
\hline AEA Summer Program & $\begin{array}{c}0.244 * * * \\
(0.045)\end{array}$ & $\begin{array}{c}0.217 * * * \\
(0.049)\end{array}$ & $\begin{array}{c}0.277 * * * \\
(0.053)\end{array}$ & $\begin{array}{c}0.228 * * * \\
(0.055)\end{array}$ & $\begin{array}{c}0.301 * * * \\
(0.071)\end{array}$ & $\begin{array}{l}0.300^{* * *} \\
(0.074)\end{array}$ \\
\hline Age & & $\begin{array}{l}-0.009 \\
(0.022)\end{array}$ & & $\begin{array}{l}0.059^{*} \\
(0.031)\end{array}$ & & $\begin{array}{c}0.072 \\
(0.068)\end{array}$ \\
\hline $\operatorname{Age}^{2}(\div 100)$ & & $\begin{array}{c}0.012 \\
(0.027)\end{array}$ & & $\begin{array}{l}-0.077^{*} \\
(0.041)\end{array}$ & & $\begin{array}{l}-0.082 \\
(0.084)\end{array}$ \\
\hline Female & & $\begin{array}{l}-0.059 \\
(0.047)\end{array}$ & & $\begin{array}{c}0.002 \\
(0.055)\end{array}$ & & $\begin{array}{c}0.022 \\
(0.083)\end{array}$ \\
\hline Hispanic & & $\begin{array}{l}0.136^{*} \\
(0.071)\end{array}$ & & $\begin{array}{l}0.209^{* *} \\
(0.081)\end{array}$ & & $\begin{array}{l}-0.033 \\
(0.159)\end{array}$ \\
\hline Black & & $\begin{array}{l}-0.007 \\
(0.086)\end{array}$ & & $\begin{array}{c}0.101 \\
(0.101)\end{array}$ & & $\begin{array}{l}-0.152 \\
(0.193)\end{array}$ \\
\hline Other & & $\begin{array}{c}0.014 \\
(0.088)\end{array}$ & & $\begin{array}{c}0.083 \\
(0.114)\end{array}$ & & $\begin{array}{l}-0.114 \\
(0.169)\end{array}$ \\
\hline $\begin{array}{l}\text { \# of undergraduate } \\
\text { institutions attended }\end{array}$ & & $\begin{array}{l}-0.008 \\
(0.030)\end{array}$ & & $\begin{array}{l}-0.051 \\
(0.035)\end{array}$ & & $\begin{array}{c}-0.122 * * * \\
(0.047)\end{array}$ \\
\hline BA from an $\mathrm{HBCU}$ & & $\begin{array}{c}0.041 \\
(0.064)\end{array}$ & & $\begin{array}{c}0.007 \\
(0.074)\end{array}$ & & $\begin{array}{c}0.089 \\
(0.108)\end{array}$ \\
\hline BA from an elite institution & & $\begin{array}{l}-0.035 \\
(0.053)\end{array}$ & & $\begin{array}{l}-0.036 \\
(0.064)\end{array}$ & & $\begin{array}{c}0.006 \\
(0.086)\end{array}$ \\
\hline $\begin{array}{l}\text { At least one parent has } \\
\text { graduate degree }\end{array}$ & & $\begin{array}{c}0.216^{* * *} \\
(0.049)\end{array}$ & & $\begin{array}{c}0.233 * * * \\
(0.058)\end{array}$ & & $\begin{array}{l}0.170^{* *} \\
(0.083)\end{array}$ \\
\hline Number of Observations & 436 & 436 & 292 & 292 & 158 & 158 \\
\hline R-squared & 0.054 & 0.121 & 0.083 & 0.178 & 0.098 & 0.189 \\
\hline
\end{tabular}

Note: Regressions with covariates impute missing values in covariates. For continuous covariates, we impute the missing values by the treatment/comparison group mean and include imputation dummies in regressions. For dummies, we impute the missing values by 0 and include imputation dummies in regressions. The list of covariates listed in this table, plus imputation dummies and a constant term, constitute the full specification for column (2), (4), and (6). It is also the specification used for treatment effect with covariates in Table 3 and Appendix Table 1."Elite" institutions are those identified as those that are "very competitive and very high research activity" by the 2010 Carnegie Classification. Robust standard are errors in parentheses. *, **, *** represent $\mathrm{p}<0.01, \mathrm{p}<0.05, \mathrm{p}<0.1$, respectively. 
Appendix Table 3L: Impact of AEA Summer Program on Ever Had an Econ-Related Academic Job

\begin{tabular}{|c|c|c|c|c|c|c|}
\hline \multirow[b]{2}{*}{ Variables } & \multicolumn{2}{|c|}{ Full Sample } & \multicolumn{2}{|c|}{ Balanced Sample } & \multicolumn{2}{|c|}{ Pre-2003 Balanced } \\
\hline & $(1)$ & $(2)$ & $(3)$ & $(4)$ & $(5)$ & (6) \\
\hline AEA Summer Program & $\begin{array}{c}0.146 * * * \\
(0.033)\end{array}$ & $\begin{array}{c}0.102 * * * \\
(0.035)\end{array}$ & $\begin{array}{c}0.117 * * * \\
(0.038)\end{array}$ & $\begin{array}{l}0.101 * * \\
(0.039)\end{array}$ & $\begin{array}{c}0.180 * * * \\
(0.058)\end{array}$ & $\begin{array}{l}0.147 * * \\
(0.065)\end{array}$ \\
\hline Age & & $\begin{array}{c}0.022 \\
(0.017)\end{array}$ & & $\begin{array}{l}0.053 * * \\
(0.022)\end{array}$ & & $\begin{array}{c}0.036 \\
(0.055)\end{array}$ \\
\hline $\operatorname{Age}^{2}(\div 100)$ & & $\begin{array}{l}-0.016 \\
(0.021)\end{array}$ & & $\begin{array}{l}-0.057 * \\
(0.029)\end{array}$ & & $\begin{array}{l}-0.037 \\
(0.068)\end{array}$ \\
\hline Female & & $\begin{array}{l}-0.065^{*} \\
(0.036)\end{array}$ & & $\begin{array}{l}-0.028 \\
(0.041)\end{array}$ & & $\begin{array}{l}-0.101 \\
(0.075)\end{array}$ \\
\hline Hispanic & & $\begin{array}{l}-0.051 \\
(0.060)\end{array}$ & & $\begin{array}{l}-0.015 \\
(0.070)\end{array}$ & & $\begin{array}{l}-0.070 \\
(0.142)\end{array}$ \\
\hline Black & & $\begin{array}{l}-0.067 \\
(0.069)\end{array}$ & & $\begin{array}{c}0.004 \\
(0.081)\end{array}$ & & $\begin{array}{l}-0.038 \\
(0.164)\end{array}$ \\
\hline Other & & $\begin{array}{c}0.048 \\
(0.070)\end{array}$ & & $\begin{array}{c}0.063 \\
(0.081)\end{array}$ & & $\begin{array}{l}-0.012 \\
(0.137)\end{array}$ \\
\hline $\begin{array}{l}\text { \# of undergraduate } \\
\text { institutions attended }\end{array}$ & & $\begin{array}{l}-0.011 \\
(0.023)\end{array}$ & & $\begin{array}{c}-0.054 * * \\
(0.022)\end{array}$ & & $\begin{array}{l}-0.054 \\
(0.041)\end{array}$ \\
\hline BA from an $\mathrm{HBCU}$ & & $\begin{array}{l}-0.035 \\
(0.049)\end{array}$ & & $\begin{array}{l}-0.063 \\
(0.053)\end{array}$ & & $\begin{array}{l}-0.122 \\
(0.082)\end{array}$ \\
\hline BA from an elite institution & & $\begin{array}{l}-0.085 * * \\
(0.040)\end{array}$ & & $\begin{array}{l}-0.067 \\
(0.046)\end{array}$ & & $\begin{array}{l}-0.093 \\
(0.077)\end{array}$ \\
\hline $\begin{array}{l}\text { At least one parent has } \\
\text { graduate degree }\end{array}$ & & $\begin{array}{l}0.100 * * \\
(0.040)\end{array}$ & & $\begin{array}{l}0.099 * * \\
(0.044)\end{array}$ & & $\begin{array}{c}0.079 \\
(0.071)\end{array}$ \\
\hline Number of Observations & 443 & 443 & 295 & 295 & 159 & 159 \\
\hline R-squared & 0.032 & 0.101 & 0.029 & 0.117 & 0.052 & 0.125 \\
\hline
\end{tabular}

Note: Regressions with covariates impute missing values in covariates. For continuous covariates, we impute the missing values by the treatment/comparison group mean and include imputation dummies in regressions. For dummies, we impute the missing values by 0 and include imputation dummies in regressions. The list of covariates listed in this table, plus imputation dummies and a constant term, constitute the full specification for column (2), (4), and (6). It is also the specification used for treatment effect with covariates in Table 3 and Appendix Table 1."Elite" institutions are those identified as those that are "very competitive and very high research activity" by the 2010 Carnegie Classification. Robust standard are errors in parentheses. *, **, *** represent $\mathrm{p}<0.01, \mathrm{p}<0.05, \mathrm{p}<0.1$, respectively. 
Appendix Table 3M: Impact of AEA Summer Program on Current Gross Annual Income

\begin{tabular}{|c|c|c|c|c|c|c|}
\hline \multirow[b]{2}{*}{ Variables } & \multicolumn{2}{|c|}{ Full Sample } & \multicolumn{2}{|c|}{ Balanced Sample } & \multicolumn{2}{|c|}{ Pre-2003 Balanced } \\
\hline & $(1)$ & $(2)$ & $(3)$ & $(4)$ & $(5)$ & $(6)$ \\
\hline \multirow[t]{2}{*}{ AEA Summer Program } & $0.409 * * *$ & $0.191 *$ & 0.179 & 0.109 & 0.130 & 0.110 \\
\hline & $(0.111)$ & $(0.111)$ & $(0.126)$ & $(0.121)$ & $(0.125)$ & $(0.115)$ \\
\hline \multirow[t]{2}{*}{ Age } & & $0.121 * * *$ & & 0.006 & & 0.006 \\
\hline & & $(0.042)$ & & $(0.082)$ & & $(0.090)$ \\
\hline \multirow[t]{2}{*}{$\operatorname{Age}^{2}(\div 100)$} & & $-0.103 * *$ & & 0.055 & & 0.041 \\
\hline & & $(0.048)$ & & $(0.105)$ & & $(0.106)$ \\
\hline \multirow[t]{2}{*}{ Female } & & -0.073 & & -0.117 & & $-0.283 * *$ \\
\hline & & $(0.080)$ & & $(0.111)$ & & $(0.131)$ \\
\hline \multirow[t]{2}{*}{ Hispanic } & & -0.069 & & -0.085 & & -0.142 \\
\hline & & $(0.129)$ & & $(0.160)$ & & $(0.247)$ \\
\hline \multirow[t]{2}{*}{ Black } & & -0.137 & & -0.191 & & -0.196 \\
\hline & & $(0.131)$ & & $(0.178)$ & & $(0.257)$ \\
\hline \multirow[t]{2}{*}{ Other } & & -0.163 & & -0.210 & & $-0.394 *$ \\
\hline & & $(0.127)$ & & $(0.183)$ & & $(0.219)$ \\
\hline \multirow{2}{*}{$\begin{array}{l}\text { \# of undergraduate } \\
\text { institutions attended }\end{array}$} & & $-0.145^{* *}$ & & $-0.207^{*}$ & & -0.126 \\
\hline & & $(0.067)$ & & $(0.106)$ & & $(0.090)$ \\
\hline \multirow[t]{2}{*}{ BA from an $\mathrm{HBCU}$} & & 0.088 & & 0.075 & & -0.142 \\
\hline & & $(0.113)$ & & $(0.158)$ & & $(0.187)$ \\
\hline \multirow[t]{2}{*}{ BA from an elite institution } & & $0.392 * * *$ & & $0.398 * * *$ & & $0.468 * * *$ \\
\hline & & $(0.087)$ & & & & $(0.122)$ \\
\hline \multirow{2}{*}{$\begin{array}{l}\text { At least one parent has } \\
\text { graduate degree }\end{array}$} & & $0.190 * *$ & & $0.217^{*}$ & & $0.213^{*}$ \\
\hline & & $(0.079)$ & & $(0.110)$ & & $(0.123)$ \\
\hline Number of Observations & 332 & 332 & 220 & 220 & 131 & 131 \\
\hline R-squared & 0.049 & 0.282 & 0.009 & 0.249 & 0.008 & 0.372 \\
\hline
\end{tabular}

Note: Regressions with covariates impute missing values in covariates. For continuous covariates, we impute the missing values by the treatment/comparison group mean and include imputation dummies in regressions. For dummies, we impute the missing values by 0 and include imputation dummies in regressions. The list of covariates listed in this table, plus imputation dummies and a constant term, constitute the full specification for column (2), (4), and (6). It is also the specification used for treatment effect with covariates in Table 3 and Appendix Table 1."Elite" institutions are those identified as those that are "very competitive and very high research activity" by the 2010 Carnegie Classification. Robust standard are errors in parentheses. *, **,*** represent $\mathrm{p}<0.01, \mathrm{p}<0.05, \mathrm{p}<0.1$, respectively. 